\title{
Moiapu 3: Settlement on Moiapu Hill at the very end of Lapita, Caution Bay hinterland
}

\author{
Bruno David, Ken Aplin, Helene Peck, Robert Skelly, Matthew \\ Leavesley, Jerome Mialanes, Katherine Szabó, Brent Koppel, Fiona \\ Petchey, Thomas Richards, Sean Ulm, lan J. McNiven, Cassandra \\ Rowe, Samantha J. Aird, Patrick Faulkner and Anne Ford
}

\begin{abstract}
The Caution Bay archaeological project on the south coast of mainland Papua New Guinea has excavated 122 sites over a $9 \mathrm{~km}^{2}$ area. Lapita ceramics appear at a number of sites at c. 2900 cal. BP. Here we present the results of excavations at Moiapu 3, a site that helps define the end of the dentate-stamped Lapita phase of this region. It is suggested that the decline and ultimate cessation of dentate stamping related to a loss of symbolism during a period of major socioeconomic readjustment and innovation.
\end{abstract}

\section{Introduction}

Fundamental to the archaeological project is our capacity to determine a beginning and an end, in both space and time, for particular kinds of cultural behaviour. However, this objective is complicated by the fact that cultures are inherently dynamic, and we must therefore be able to also account for transformations that bridge so-called beginnings and endings. We may be able to identify a beginning, and similarly an end, for when certain ways of doing things ceased, but it is in the context of longer genealogies that history, and a nuanced understanding of history, operate. We may achieve this aim of exploring genealogies of cultural expression by reference to archaeological datasets that register the initiation of specific characteristics, but it is by understanding what happened before and after that they allow us to see their place in history.

In Island Melanesia and parts of mainland New Guinea, one cultural expression that has long raised the interest of archaeologists is Lapita, made up of a set of archaeological objects that is identifiable especially through the dentate-stamped ceramics that help define it, but that also includes many other kinds of material culture together known as the 'Lapita Cultural Complex'. Lapita ceramics suddenly commence around $3300 \mathrm{cal}$. BP (Denham et al. 2012) or even a bit later (cf. Petchey et al. 2014:241) in islands of the Bismarck Archipelago, rapidly spread across a wide geographical expanse, and over the ensuing few hundred years perdure in recognisable form and decorative design until in some regions they cease entirely, while in others they transform into 
something else. While there have been significant attempts to date, track and model the onset of Lapita in Melanesia, the nature and timing of its cessation remains largely uncertain for many parts of the Lapita world.

At Caution Bay, located near Port Moresby on the south coast of Papua New Guinea (PNG), we have an ideal opportunity to assess the beginning and end of the Lapita Cultural Complex for this area, based on evidence drawn from a suite of well-dated sites that have high chronostratigraphic resolution (Figure 3.1). Here the beginning of Lapita ceramics is manifest by the sudden appearance of dentate-stamped pottery in layers dated to $2900 \mathrm{cal}$. BP. Its end is now the subject of intensive study at a number of sites where there is evidence for dentate-stamped and/or post-dentate-stamped ceramics. Because most, but not all, sites are of limited duration, we focus on dating and characterising the ceramics and other types of cultural materials on either side of the dentate-stamped/post-dentate-stamped divide in all relevant excavated sites within the Caution Bay study region. Many sites have large dense cultural deposits of relatively short duration, bracketed both before and after by demonstrably sterile sediments. Such sites usefully form a suite of cultural sequences that together provide data that enable us reliably to model broader trends across the Caution Bay landscape. In practice, such an approach has been possible because of the sheer density of excavations undertaken across the landscape, in total sampling 122 sites $^{1}$ over a 3 by $3 \mathrm{~km}$ area. The sum of these data is shedding a clear and consistent picture of the timing of the transition out of Lapita, enabling better understanding of what happened to the 'Lapita peoples' of Caution Bay after the end of the identifiably Lapita period.

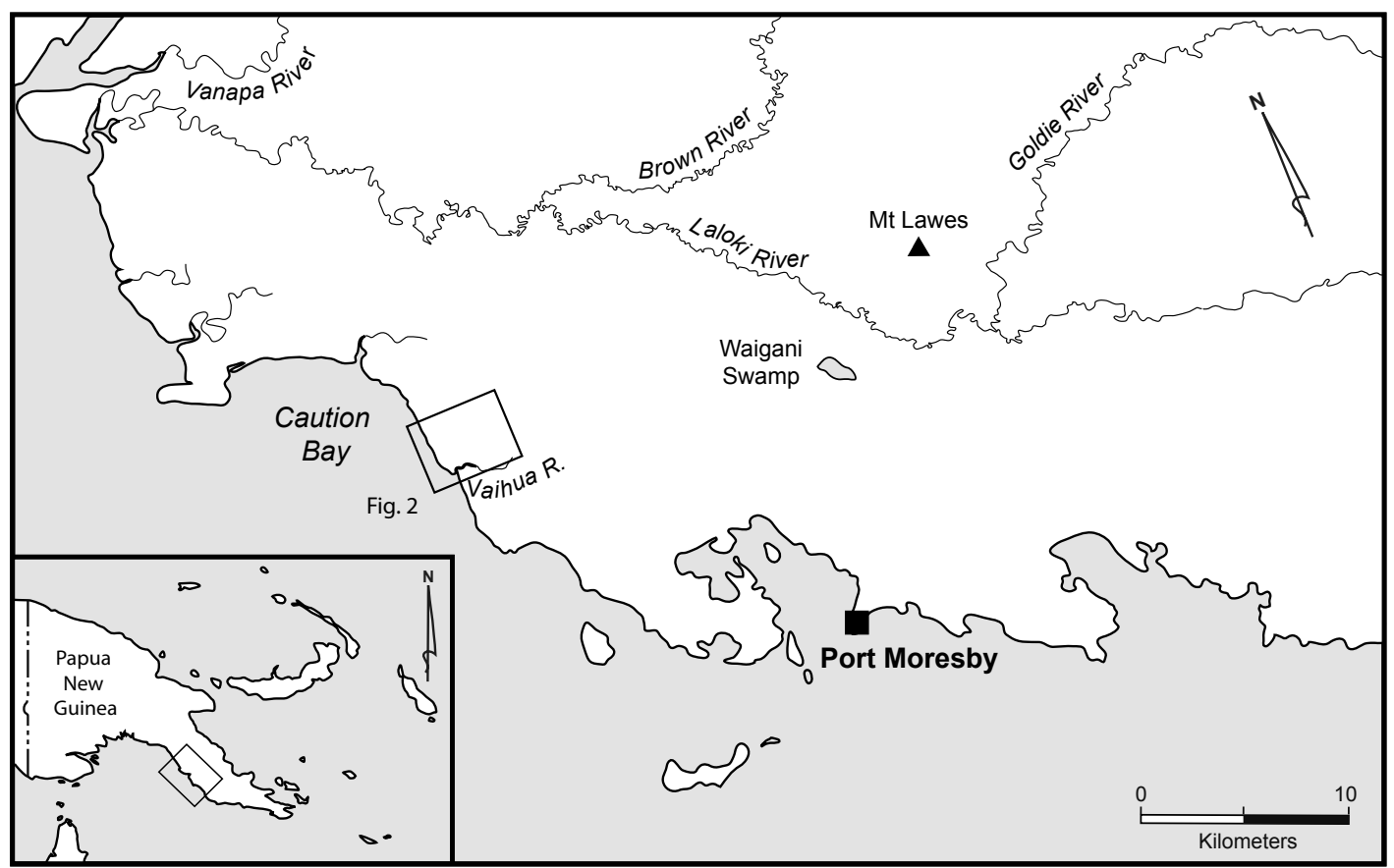

Figure 3.1. Location of study region in Caution Bay, south coast of Papua New Guinea.

Source: Drafted by Kara Rasmanis.

In this chapter, we present the results of excavations at Moiapu 3, a site that helps define the immediate Post-Lapita period for Caution Bay. Moiapu 3 will then be used as a context to discuss the area's archaeological sequence in light of what else has been found for the period straddling

1 In the Caution Bay project, an archaeological 'site' is defined as a location of cultural materials $15 \mathrm{~m}$ or more from its closest neighbour. An archaeological site is thus an expression of recording criteria for emplaced cultural materials rather than a distinct functional (occupational) location such as a village or short-term activity area. 
the end of dentate-stamped ceramics at other Caution Bay sites. We are very conscious that Lapita is more than dentate-stamped ceramics, but we focus on the period on either side of such ceramics because they help define, without ambiguity, the demonstrably Lapita horizon. The presentation of the full range of cultural materials from Moiapu 3 in relation to the Lapita Cultural Complex allows us to consider notions of both change and continuity within and out of Lapita. We will return to these issues in the Discussion below.

\section{Moiapu 3}

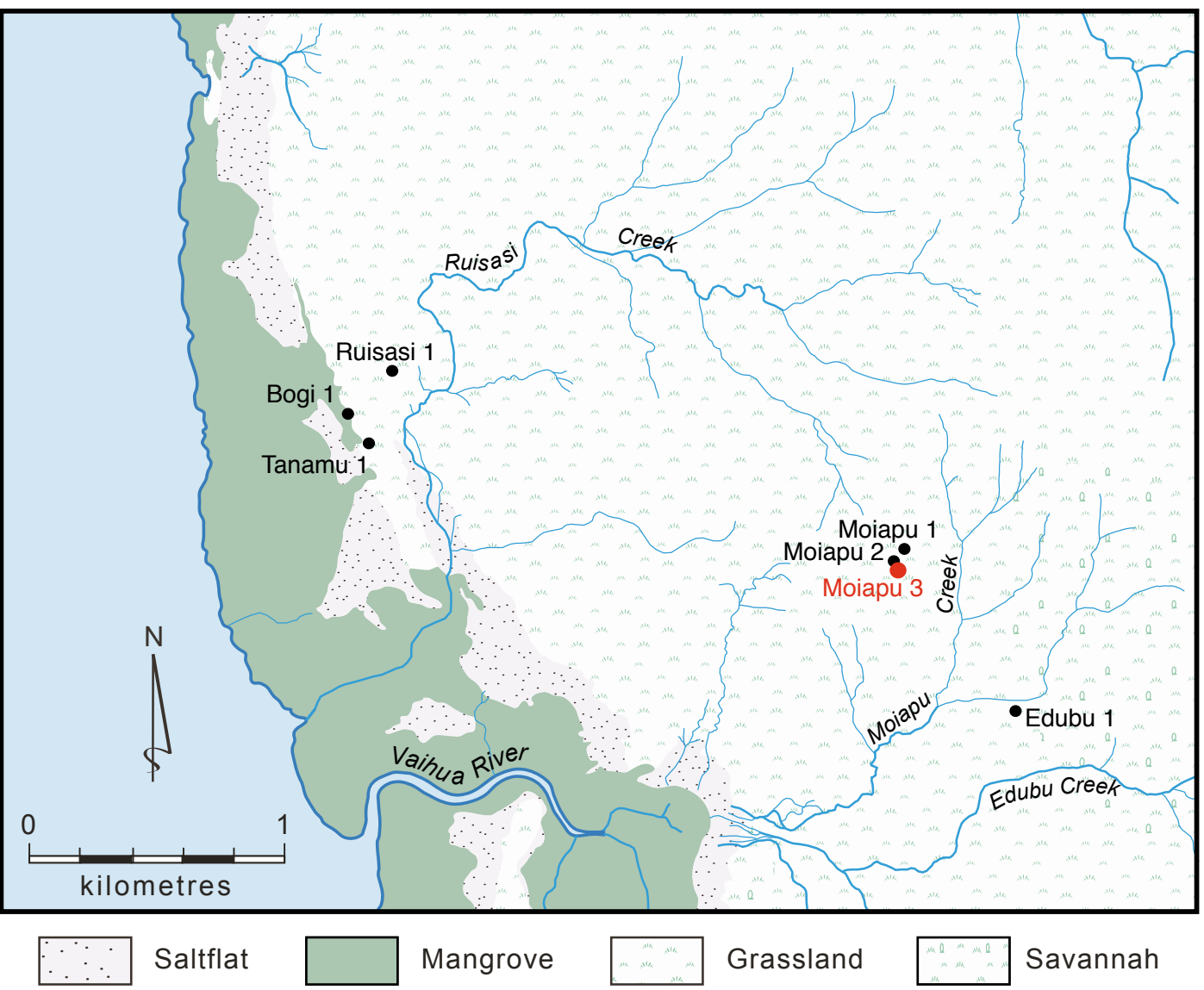

Figure 3.2. Topographic map showing location of Moiapu 3 (red) relative to other excavated Caution Bay sites discussed in this paper.

Source: Drafted by Kara Rasmanis.

On 29 March 2009, Robert Skelly and his team were surveying for archaeological sites along a low, 600-metre-long SSW-NNE trending ridge locally known as 'Moiapu', located from $900 \mathrm{~m}$ to $1550 \mathrm{~m}$ inland of coastal intertidal mudflats in the Caution Bay hinterland (Figure 3.2). Moiapu 3 was identified during these surveys as a low-density scatter of pottery sherds, stone artefacts and shell spread over an area measuring 60 by $51 \mathrm{~m}$ along the Moiapu ridge line. This site was allocated the PNG National Museum and Art Gallery site code AAZD. To the south of the site, the ground gradually rises for $60 \mathrm{~m}$ to Moiapu Hill, a local topographic high point. To the north and north-east, grasslands slope down gently for c. $1 \mathrm{~km}$ before reaching abruptly rising inland hills. Moiapu 3 is on the windy exposed eastern flank of the elevated ridge. Further to the east, the ground slopes down gently to expansive open grassland on coastal plains. The site 
offers strategic views in all directions across the plains except directly to the south, where views are interrupted by Moiapu Hill itself. A seasonal supply of freshwater is available $250 \mathrm{~m}$ to the south-west. The closest permanent water source is Ruisasi Creek, $500 \mathrm{~m}$ to the north-west.

From 14 to 19 March 2010, a 1 by $1 \mathrm{~m}$ archaeological excavation was undertaken towards the northern and higher parts of Moiapu 3 (Figures 3.3 and 3.4).

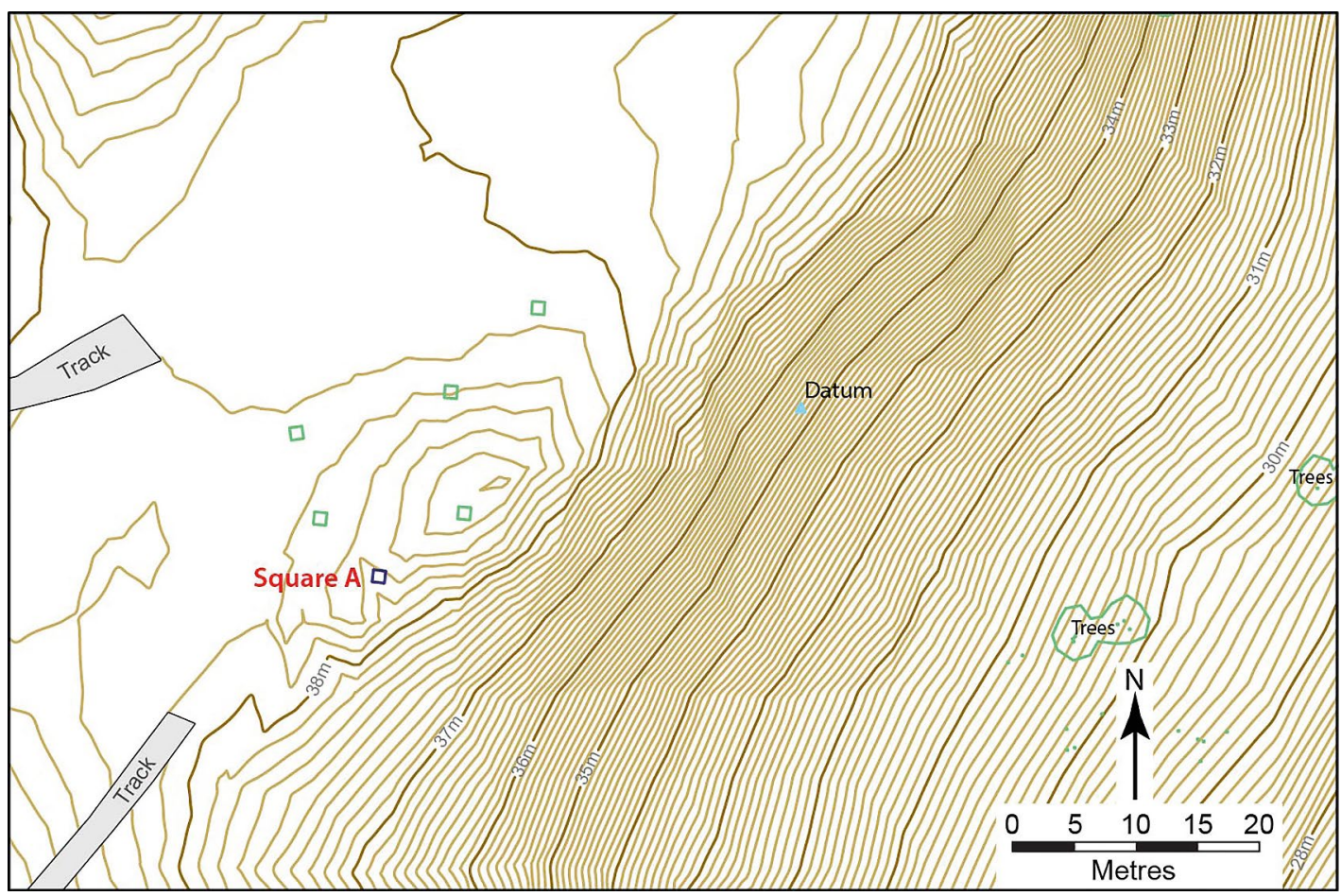

Figure 3.3. Topographic map showing location of the Moiapu 3 excavation square (red). Green squares are the nearby Moiapu 2 excavation squares.

Source: Drafted by Bruno David from original surveys by Lynden McGregor of Geomatix.
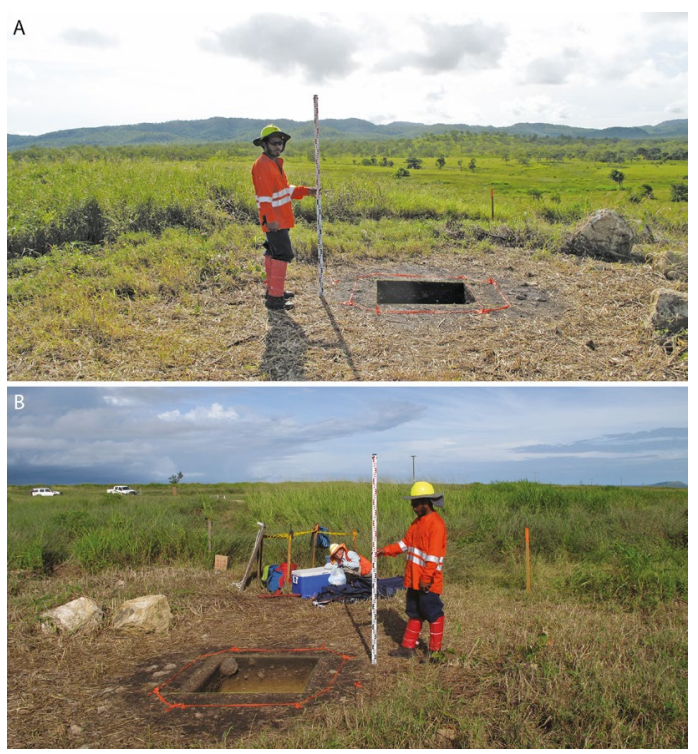

Figure 3.4. View east (A) and west (B) from Moiapu 3, March 2010.

Source: Photos by Robert Skelly.

\section{Field and laboratory methods}

The square was excavated in 31 arbitrary excavation units (XUs) within stratigraphic units (SUs), with XUs averaging $2.0 \pm 0.5 \mathrm{~cm}$ thick. However, the cultural excavation units (XU1-XU17) of SU1, SU2 and the SU2-SU3 interface were dug in mean $1.8 \pm 0.5$-cm-thick $\mathrm{XUs}$, with the underlying XU18-XU31 of non-cultural SU3 dug in mean $2.3 \pm 0.3-\mathrm{cm}$ thick XUs. Bulk sediment samples were collected from each XU. Excavation proceeded to a maximum depth of $62 \mathrm{~cm}$, ceasing well into culturally sterile sediments. The lowermost XUs (XU25-XU31) in basal non-cultural sediments consist of one 50 by $50 \mathrm{~cm}$ quadrant of the square only (Table 3.1; Figures 3.5 and 3.6).

\section{terira australis 52}


Artefacts $>3 \mathrm{~cm}$ in length and selected charcoal samples were plotted in three dimensions and individually bagged. Handling of archaeological items was avoided as much as possible both in the field and in the laboratory. Photographs were taken of the base of the square at the end of each XU; particularly important finds encountered in situ were also photographed during the excavation. At the end of the excavation, all four walls of the square were photographed, and section drawings were made of the east and south profiles (Figures 3.5 and 3.6). All excavated materials except for the bulk sediment samples were wet-sieved in 2.1-mm-mesh sieves, with the retained material sorted under controlled laboratory conditions.

Table 3.1. Details of XUs, Moiapu 3. Bold indicates dominant SU.

\begin{tabular}{|c|c|c|c|c|c|c|c|c|c|}
\hline$X U$ & SU & $\begin{array}{l}\text { Mean depth } \\
\text { at top }(\mathrm{cm})\end{array}$ & $\begin{array}{c}\text { Mean depth at } \\
\text { centre }(\mathrm{cm})\end{array}$ & $\begin{array}{l}\text { Mean depth } \\
\text { at base }(\mathrm{cm})\end{array}$ & $\begin{array}{l}\text { Mean thickness } \\
(\mathrm{cm})\end{array}$ & $\begin{array}{l}\text { Area } \\
\text { (m2) }\end{array}$ & $\begin{array}{l}\text { Weight } \\
\text { (kg) }\end{array}$ & $\begin{array}{l}\text { Volume } \\
\text { (litres) }\end{array}$ & $\mathrm{pH}$ \\
\hline 1 & 1 & 0 & 0.2 & 0.4 & 0.4 & 1.00 & 5.21 & 7.0 & - \\
\hline 2 & 1 & 0.4 & 1.4 & 2.3 & 1.9 & 1.00 & 24.18 & 29.5 & - \\
\hline 3 & 1 & 2.3 & 3.3 & 4.2 & 1.9 & 1.00 & 30.01 & 34.0 & 7.82 \\
\hline 4 & 1 & 4.2 & 5.2 & 6.1 & 1.9 & 1.00 & 27.63 & 28.0 & - \\
\hline 5 & $1+2$ & 6.1 & 7.2 & 8.2 & 2.1 & 1.00 & 33.66 & 36.0 & - \\
\hline 6 & $1+2$ & 8.2 & 9.0 & 9.7 & 1.5 & 1.00 & 23.23 & 23.0 & - \\
\hline 7 & $1+2$ & 9.7 & 10.5 & 11.3 & 1.6 & 1.00 & 28.76 & 27.0 & - \\
\hline 8 & $1+2$ & 11.3 & 12.4 & 13.5 & 2.2 & 1.00 & 34.08 & 30.0 & - \\
\hline 9 & $1+2$ & 13.5 & 14.2 & 14.9 & 1.4 & 1.00 & 31.44 & 26.0 & - \\
\hline 10 & $1+2$ & 14.9 & 16.2 & 17.4 & 2.5 & 1.00 & 32.52 & 28.0 & 8.08 \\
\hline 11 & $2+3$ & 17.4 & 18.3 & 19.2 & 1.8 & 1.00 & 32.83 & 27.0 & - \\
\hline 12 & $2+3$ & 19.2 & 19.9 & 20.5 & 1.3 & 1.00 & 28.19 & 23.0 & - \\
\hline 13 & $2+3$ & 20.5 & 21.4 & 22.3 & 1.8 & 1.00 & 30.50 & 29.5 & - \\
\hline 14 & $2+3$ & 22.3 & 23.3 & 24.2 & 1.9 & 1.00 & 31.75 & 34.5 & 8.15 \\
\hline 15 & $2+3$ & 24.2 & 25.2 & 26.2 & 2.0 & 1.00 & 33.84 & 31.0 & - \\
\hline 16 & $2+3$ & 26.2 & 27.2 & 28.1 & 1.9 & 1.00 & 33.97 & 31.0 & - \\
\hline 17 & $2+3$ & 28.1 & 29.3 & 30.4 & 2.3 & 1.00 & 32.47 & 31.5 & - \\
\hline 18 & 3 & 30.4 & 31.4 & 32.4 & 2.0 & 1.00 & 39.31 & 38.0 & - \\
\hline 19 & 3 & 32.4 & 33.4 & 34.4 & 2.0 & 1.00 & 35.00 & 33.0 & - \\
\hline 20 & 3 & 34.4 & 35.6 & 36.7 & 2.3 & 1.00 & 38.32 & 37.0 & - \\
\hline 21 & 3 & 36.7 & 37.7 & 38.7 & 2.0 & 1.00 & 35.84 & 35.0 & 8.33 \\
\hline 22 & 3 & 38.7 & 39.7 & 40.7 & 2.0 & 1.00 & 40.92 & 38.5 & - \\
\hline 23 & 3 & 40.7 & 41.8 & 42.9 & 2.2 & 1.00 & 41.30 & 37.0 & - \\
\hline 24 & 3 & 42.9 & 43.9 & 44.9 & 2.0 & 1.00 & 39.20 & 36.0 & - \\
\hline 25 & 3 & 44.9 & 46.1 & 47.3 & 2.4 & 0.25 & 7.53 & 7.5 & - \\
\hline 26 & 3 & 47.3 & 48.5 & 49.7 & 2.4 & 0.25 & 10.94 & 9.0 & - \\
\hline 27 & 3 & 49.7 & 50.8 & 51.9 & 2.2 & 0.25 & 9.90 & 9.0 & - \\
\hline 28 & 3 & 51.9 & 53.4 & 54.9 & 3.0 & 0.25 & 13.16 & 11.5 & - \\
\hline 29 & 3 & 54.9 & 56.0 & 57.1 & 2.2 & 0.25 & 9.73 & 9.0 & - \\
\hline 30 & 3 & 57.1 & 58.5 & 59.9 & 2.8 & 0.25 & 10.80 & 10.0 & - \\
\hline 31 & 3 & 59.9 & 61.0 & 62.0 & 2.1 & 0.25 & 9.88 & 9.0 & 8.42 \\
\hline Total & & & & & & & 836.10 & 795.5 & \\
\hline
\end{tabular}

Source: Authors' data.

\section{Stratigraphy}

Moiapu 3's stratigraphy comprises three major SUs. Each SU is fairly flat and horizontal. From the surface down, SU1 consists of homogeneous, poorly consolidated very dark gray (dry Munsell: 10YR 3/1) silty loam containing 13.1 per cent organic matter (by weight) that includes fine grass rootlets, local limestone rocks and minor quantities of cultural materials. SU1 is typically 
c. $10 \mathrm{~cm}$ thick and quickly gives way to SU2, a very dark grayish brown (dry Munsell: 10YR $3 / 2$ ) consolidated silty loam (organic matter $=8.2-9.0$ per cent). SU2 is a cultural horizon densely packed with unsorted limestone rubble, pottery sherds, stone artefacts and faunal remains (especially inshore marine shell). The interface between SU1 and SU2 is marked, typically c. $2 \mathrm{~cm}$ thick. SU2 is itself typically c. $10 \mathrm{~cm}$ thick, transitioning to SU3 below a c. 5-cm-thick SU2SU3 gradual sediment interface. While minor amounts of cultural material occur within SU3, these appear to be post-depositional intrusions from above. SU3 sediments are homogeneous, consolidated pale yellow (dry Munsell: $2.5 \mathrm{Y} 7 / 3$ to $7 / 4$ ) silty loam of moderate compaction (organic matter $=4.6-5.4$ per cent). Excavation proceeded some $36 \mathrm{~cm}$ into SU3 proper without reaching bedrock.

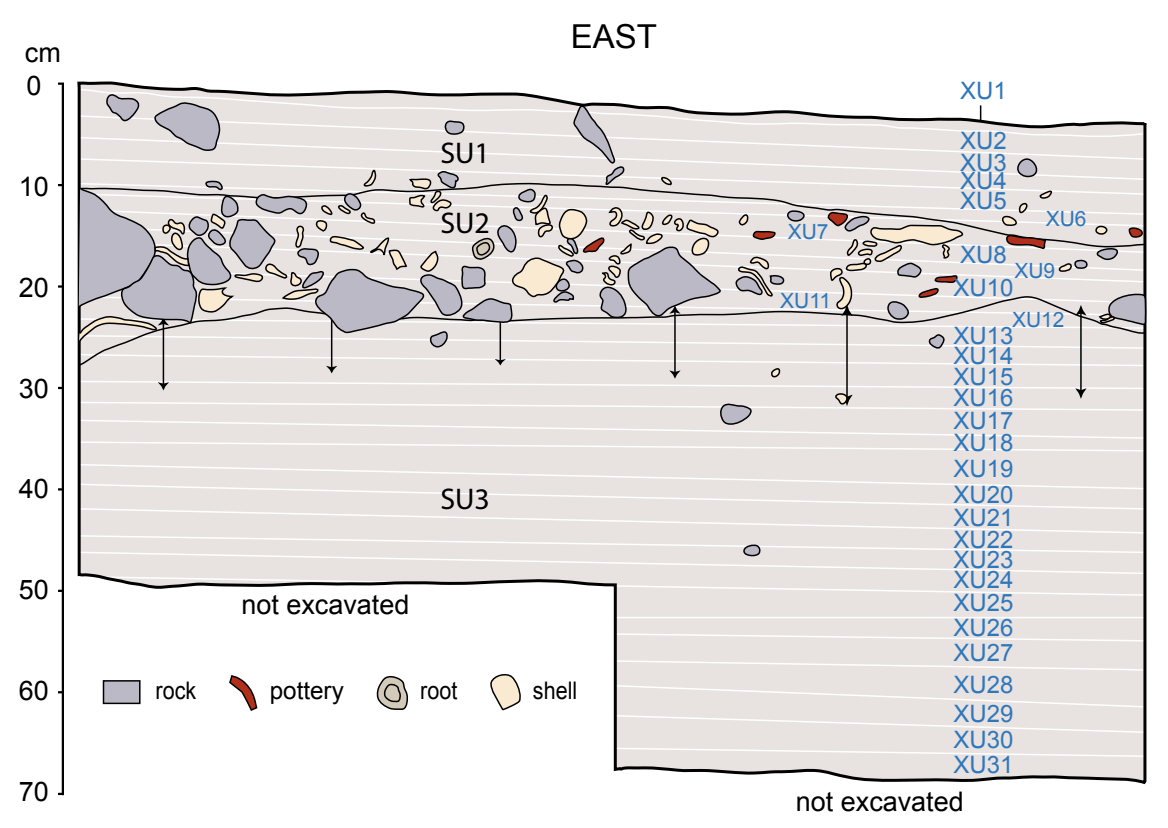

SOUTH

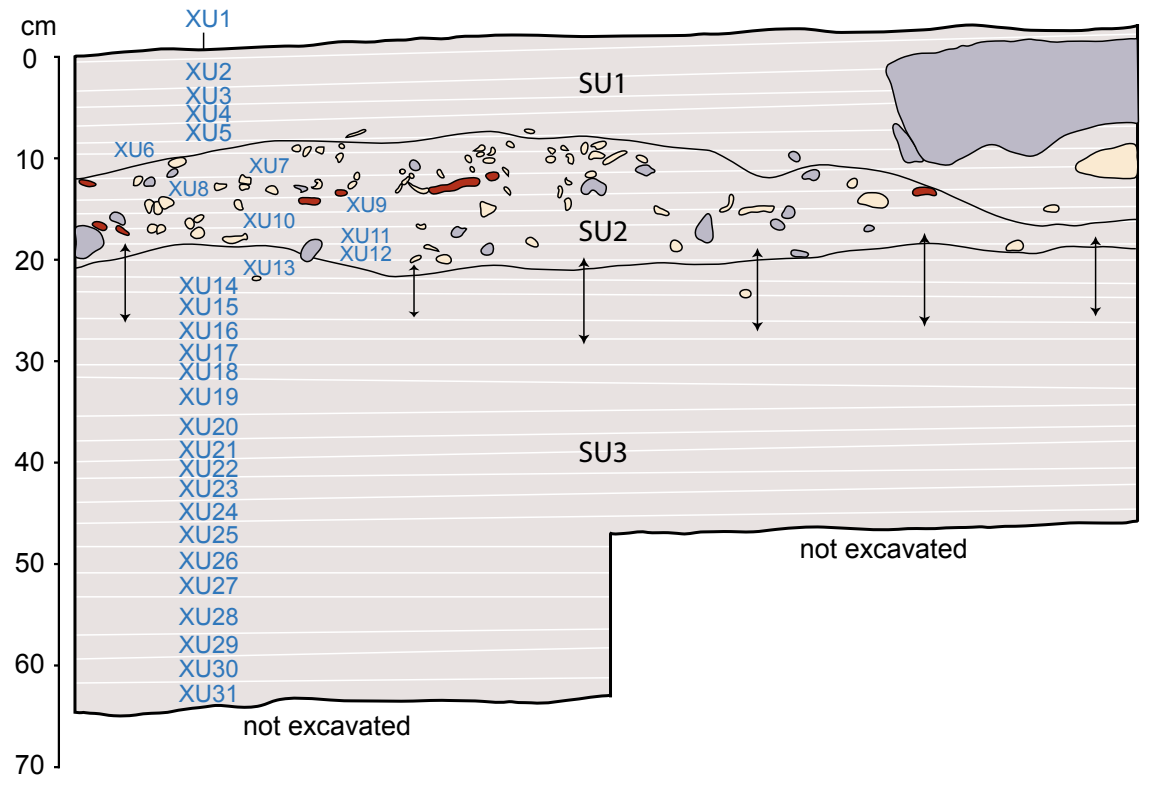

Figure 3.5. Section drawings, Moiapu 3, east and south walls showing backplotted XUs.

Source: Drafted by Kara Rasmanis. 

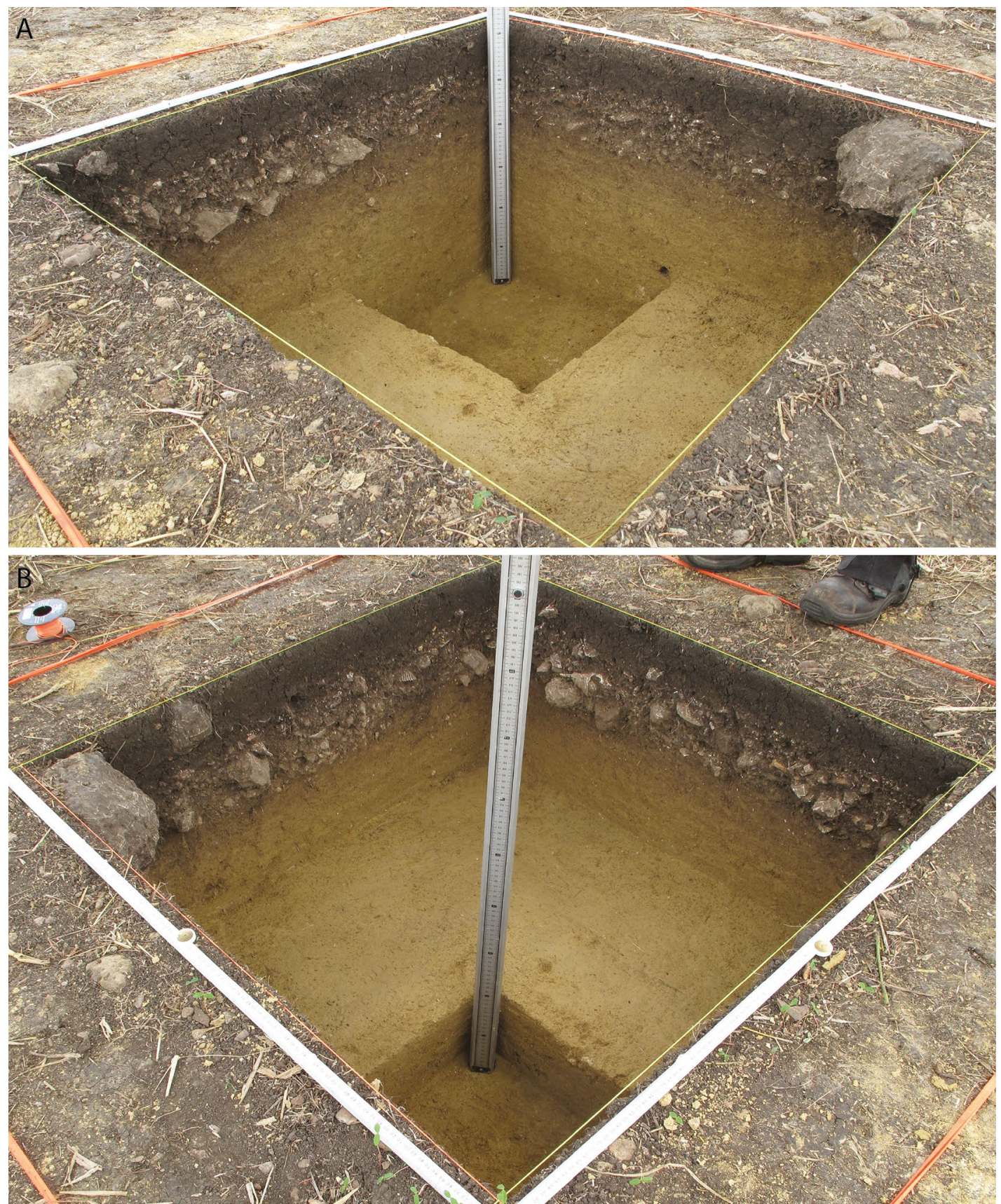

Figure 3.6. Moiapu 3, after completion of excavation. The orange string aligns with the south wall. (A) East and south walls. (B) West and north walls.

Source: Photos by Robert Skelly.

\section{Radiocarbon dating}

Six radiocarbon dates have been obtained from Moiapu 3 (Table 3.2; Figure 3.7). All are accelerator mass spectrometry (AMS) dates on single pieces of inshore marine shell obtained from the sieves. Two species of shell were used, with $\Delta \mathrm{R}$ values for each species calculated separately for this part of Caution Bay (see Petchey et al. 2012, 2013). The following discussions of calibrated ages are based on the 68.2 per cent probability calibrations. The age calibrations indicate that Moiapu 3 was occupied sometime within the period 2630-2410 cal. BP. 


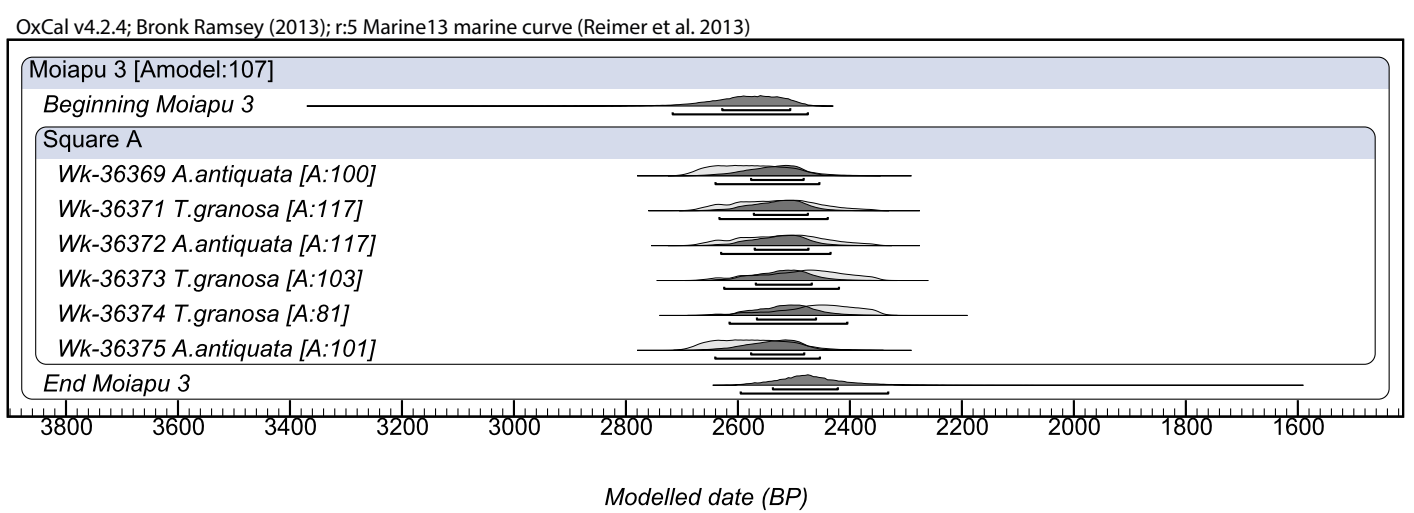

Figure 3.7. Schematics for the 0xCal single phase model (Bronk Ramsey 2009), based on all the Moiapu 3 radiocarbon determinations.

Source: Fiona Petchey.

Table 3.2. Radiocarbon determinations, Moiapu 3.

\begin{tabular}{|c|c|c|c|c|c|c|c|c|c|c|}
\hline$X U$ & $\begin{array}{l}\text { Depth } \\
\text { (cm) }\end{array}$ & SU & $\begin{array}{l}\text { Laboratory } \\
\text { code }\end{array}$ & $\begin{array}{l}\text { Marine } \\
\text { shell } \\
\text { dated }\end{array}$ & $\delta^{13} \mathrm{C} \% 0$ & $\begin{array}{c}\% \\
\text { modern }\end{array}$ & $\begin{array}{c}{ }^{14} \text { C Age } \\
\text { (years } \\
\text { BP) }\end{array}$ & $\begin{array}{c}\text { Calibrated } \\
\text { age BP } \\
(68.2 \% \\
\text { probability) }\end{array}$ & $\begin{array}{c}\text { Calibrated } \\
\text { age BP } \\
\text { (95.4\% } \\
\text { probability) }\end{array}$ & $\begin{array}{l}\text { Median } \\
\text { calibrated } \\
\text { age BP }\end{array}$ \\
\hline 2 & $0.4-2.3$ & 1 & Wk-36369 & $\begin{array}{l}\text { Anadara } \\
\text { antiquata }\end{array}$ & $0.5 \pm 0.2$ & $70.4 \pm 0.2$ & $2814 \pm 25$ & $2658-2517$ & $2692-2452$ & 2578 \\
\hline 6 & $8.2-9.7$ & $1+2$ & Wk-36371 & $\begin{array}{r}\text { Tegillarca } \\
\text { granosa }\end{array}$ & $-7.7 \pm 0.2$ & $71.3 \pm 0.2$ & $2714 \pm 25$ & $2611-2456$ & $2671-2396$ & 2532 \\
\hline 8 & $11.3-13.5$ & $1+2$ & Wk-36372 & $\begin{array}{l}\text { Anadara } \\
\text { antiquata }\end{array}$ & $-0.8 \pm 0.2$ & $70.8 \pm 0.2$ & $2778 \pm 25$ & $2605-2448$ & $2665-2381$ & 2521 \\
\hline 10 & $14.9-17.4$ & $1+2$ & Wk-36373 & $\begin{array}{r}\text { Tegillarca } \\
\text { granosa }\end{array}$ & $-8.5 \pm 0.2$ & $71.6 \pm 0.2$ & $2689 \pm 25$ & $2561-2395$ & $2644-2351$ & 2481 \\
\hline 12 & $19.2-20.5$ & $2+3$ & Wk-36374 & $\begin{array}{r}\text { Tegillarca } \\
\text { granosa }\end{array}$ & $-9.4 \pm 0.2$ & $71.7 \pm 0.2$ & $2674 \pm 25$ & $2501-2362$ & $2607-2341$ & 2452 \\
\hline 15 & $24.2-26.2$ & $2+3$ & Wk-36375 & $\begin{array}{l}\text { Anadara } \\
\text { antiquata }\end{array}$ & $-0.4 \pm 0.2$ & $70.5 \pm 0.2$ & $2812 \pm 25$ & $2655-2511$ & $2690-2450$ & 2575 \\
\hline
\end{tabular}

All 14C ages are AMS on single pieces of shell. Calibrations undertaken using 0xCal v4.2.4 (shell: MARINE09 curve selection, Tegillarca granosa $\Delta R=-71 \pm 15$; Anadara antiquata $\Delta R=-1 \pm 16$ ) (Bronk Ramsey 2013; Petchey et al. 2013; Reimer et al. 2013). Bold indicates dominant SU.

Source: Authors' data.

\section{Cultural materials}

Cultural materials for the most part were found in SU2, from XU5 to XU14, with a small amount of material in SU1 and SU3. The vertical distributions of all classes of cultural material have regular bell curves, with peak densities occurring in XU9 or XU10, the only exception being stone artefacts, which peak in XU11. Charcoal, which is only present in small quantities and is not necessarily cultural in origin, peaks in SU1 (XU2); this minor charcoal concentration is likely related to periodic grassland fires associated with wallaby hunting or clearing for gardening in the general area rather than with the occupation of this site. The single small piece of metal shrapnel from XU2 relates to World War II activities in the area, but the site shows no disturbance from direct shelling. 
Human occupation at Moiapu 3 occurred during the deposition of SU2; the small amounts of cultural materials above and below SU2 have likely moved there post-depositionally through vertical cracks in the sediment, which commonly occur throughout the Caution Bay clay-rich sediments ('cracking clays') opening and closing on a seasonal basis depending on moisture content.

The strong patterning in the vertical distribution of cultural materials (i.e. peaking from XU9 to XU11 in SU2) is indicative of a single period of occupation (Table 3.3). Radiocarbon age determinations from XU2 down to XU15, essentially bracketing SU2, indicate a single period of occupation (see above).

Table 3.3. General list of excavated materials by XU, Moiapu 3.

\begin{tabular}{|c|c|c|c|c|c|c|c|c|c|c|c|c|c|}
\hline \multirow[t]{2}{*}{ XU } & \multirow[t]{2}{*}{ SU } & \multirow{2}{*}{$\begin{array}{c}\text { Shell } \\
g \\
\end{array}$} & \multirow{2}{*}{\begin{tabular}{|c} 
Barnacle \\
$g$ \\
\end{tabular}} & \multirow{2}{*}{$\begin{array}{c}\text { Crab } \\
g \\
\end{array}$} & \multirow{2}{*}{\begin{tabular}{|c|c}
$\begin{array}{c}\text { Sea } \\
\text { urchin }\end{array}$ \\
9 \\
\end{tabular}} & \multirow{2}{*}{$\begin{array}{c}\text { Bone } \\
g \\
\end{array}$} & \multirow{2}{*}{$\begin{array}{c}\text { Charcoal } \\
g \\
\end{array}$} & \multicolumn{2}{|c|}{$\begin{array}{c}\text { Pottery } \\
\text { sherds }\end{array}$} & \multicolumn{2}{|c|}{$\begin{array}{c}\text { Stone } \\
\text { artefacts }\end{array}$} & \multirow{2}{*}{$\begin{array}{c}\begin{array}{c}\text { Shell } \\
\text { artefacts }\end{array} \\
g \\
\end{array}$} & \multirow{2}{*}{$\begin{array}{c}\text { Metal } \\
\text { shrapnel }\end{array}$} \\
\hline & & & & & & & & $\#$ & $g$ & $\#$ & 9 & & \\
\hline 1 & 1 & 41.8 & 0.1 & - & - & - & 0.06 & 35 & 19.8 & 15 & 2.0 & - & - \\
\hline 2 & 1 & 36.5 & 0.1 & - & 0.04 & 0.28 & 0.13 & 55 & 22.2 & 30 & 5.3 & - & 4.68 \\
\hline 3 & 1 & 38.1 & $<0.1$ & - & 0.01 & - & - & 24 & 5.2 & 16 & 0.9 & - & - \\
\hline 4 & 1 & 70.7 & 0.2 & - & - & 0.06 & 0.03 & 83 & 28.4 & 18 & 9.2 & - & - \\
\hline 5 & $1+2$ & 211.6 & 0.8 & - & - & 0.27 & - & 76 & 63.9 & 14 & 8.8 & - & - \\
\hline 6 & $1+2$ & 607.0 & 2.0 & 1.27 & - & 6.06 & - & 489 & 119.7 & 59 & 21.4 & - & - \\
\hline 7 & $1+2$ & 1939.5 & 8.0 & 1.84 & 1.97 & 19.53 & - & 1429 & 420.0 & 108 & 75.1 & 20.3 & - \\
\hline 8 & $1+2$ & 1977.5 & 6.1 & 2.03 & 4.82 & 8.40 & - & 1133 & 493.7 & 135 & 70.5 & - & - \\
\hline 9 & $1+2$ & 2901.7 & 11.9 & 3.37 & 14.68 & 22.23 & - & 1587 & 549.4 & 111 & 120.1 & - & - \\
\hline 10 & $1+2$ & 2819.6 & 12.0 & 3.22 & 41.13 & 17.74 & - & 1824 & 631.2 & 84 & 31.5 & - & - \\
\hline 11 & $2+3$ & 2149.8 & 1.2 & 2.12 & 18.61 & 10.74 & $<0.01$ & 1142 & 522.8 & 51 & 414.8 & - & - \\
\hline 12 & $2+3$ & 1233.0 & 5.6 & 1.72 & 17.32 & 6.69 & 0.06 & 646 & 208.9 & 35 & 359.0 & - & - \\
\hline 13 & $2+3$ & 370.0 & 2.0 & 0.77 & 11.66 & 1.82 & - & 180 & 37.2 & 9 & 2.4 & - & - \\
\hline 14 & $2+3$ & 159.5 & 0.2 & - & 2.50 & 0.46 & - & 50 & 24.8 & 6 & 1.1 & - & - \\
\hline 15 & $2+3$ & 2.4 & 0.1 & 0.13 & 0.86 & 0.08 & - & 39 & 12.3 & 4 & 0.6 & - & - \\
\hline 16 & $2+3$ & 87.8 & - & 0.18 & 0.99 & 0.05 & - & - & - & 2 & 0.1 & - & - \\
\hline 17 & $2+3$ & 12.7 & 0.1 & - & 0.35 & - & - & 4 & 0.4 & 2 & $<0.1$ & - & - \\
\hline 18 & 3 & 35.0 & - & - & 0.24 & 0.21 & - & 4 & 0.5 & - & - & - & - \\
\hline 19 & 3 & 1.0 & $<0.1$ & - & 0.56 & - & - & - & - & - & - & - & - \\
\hline 20 & 3 & 23.3 & - & - & 0.10 & - & - & 1 & 0.4 & - & - & - & - \\
\hline 21 & 3 & 0.4 & - & - & - & - & - & - & - & - & - & - & - \\
\hline 22 & 3 & 0.3 & - & - & 0.02 & - & - & - & - & - & - & - & - \\
\hline 23 & 3 & - & - & - & - & - & - & - & - & - & - & - & - \\
\hline 24 & 3 & - & - & - & - & - & - & - & - & - & - & - & - \\
\hline 25 & 3 & - & - & - & - & - & - & - & - & - & - & - & - \\
\hline 26 & 3 & - & - & - & - & - & - & - & - & - & - & - & - \\
\hline 27 & 3 & - & - & - & - & - & - & - & - & - & - & - & - \\
\hline 28 & 3 & - & - & - & - & - & - & - & - & - & - & - & - \\
\hline 29 & 3 & - & - & - & - & - & - & - & - & - & - & - & - \\
\hline 30 & 3 & 0.1 & - & - & - & - & - & - & - & - & - & - & - \\
\hline 31 & 3 & - & - & - & 0.28 & - & - & - & - & - & - & - & - \\
\hline Tot & & 14719.3 & 50.4 & 16.65 & 115.86 & 94.62 & 0.28 & 8801 & 3160.8 & 699 & 1122.8 & 20.3 & 4.68 \\
\hline
\end{tabular}

Bold indicates dominant SU. "Shell artefact weights are also included in the 'Shell' column weights.

Source: Authors' data. 

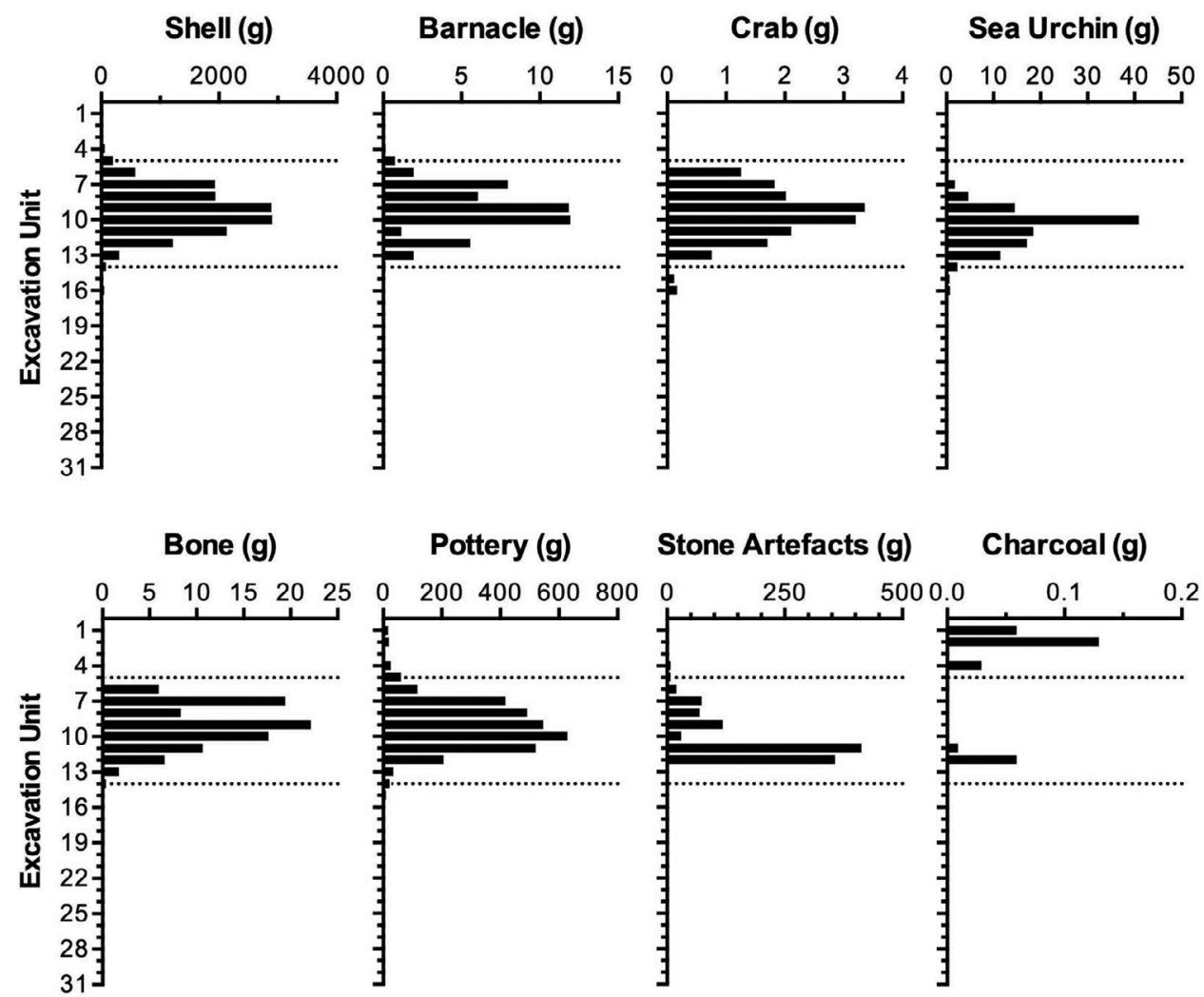

Figure 3.8. Distribution of cultural materials by weight, by XU, Moiapu 3 .

The dotted lines correspond with SU2.

Source: Jerome Mialanes.

\section{Stone artefacts}

The stone artefact assemblage consists of flaked artefacts (flakes, retouched flakes and cores), a flaked and ground axe/adze, and a grinding stone. Most of these were made of chert (Table 3.4), a locally available raw material (Davies and Smith 1971; Glaessner 1952; Mabbutt et al. 1965). Chert artefacts occur through the entire cultural sequence from XU1 down to XU17, and are most numerous from XU6 to XU12, in the dense SU2 cultural horizon (Figure 3.9). There is evidence of Table 3.4. Stone artefact raw materials, Moiapu 3.

\begin{tabular}{|l|r|r|r|r|}
\hline \multirow{2}{*}{ Raw material } & \multicolumn{2}{|c|}{ By number } & \multicolumn{2}{c|}{ By weight } \\
\cline { 2 - 5 } & \multicolumn{1}{|c|}{$\#$} & \multicolumn{1}{c|}{$\%$} & \multicolumn{1}{c|}{$\mathbf{g}$} & \multicolumn{1}{c|}{$\%$} \\
\hline Chert & 672 & 96.1 & 333.2 & 29.7 \\
\hline Obsidian & 18 & 2.6 & 2.1 & 0.2 \\
\hline Volcanic & 6 & 0.9 & 785.7 & 70.0 \\
\hline Quartz & 2 & 0.3 & 0.1 & $<0.1$ \\
\hline Chalcedony & 1 & 0.1 & 1.7 & 0.1 \\
\hline Total & 699 & 100 & 1122.8 & 100 \\
\hline
\end{tabular}
heat alteration in the form of potlid scars Source: Authors' data. on 75 (11.2 per cent) of the chert artefacts. The fact that potlid scars were found on both dorsal and ventral surfaces of flakes $(n=47$, 67.1 per cent) or ventral surfaces only $(n=7$, 10.0 per cent) indicates that heat application was post-depositional. 

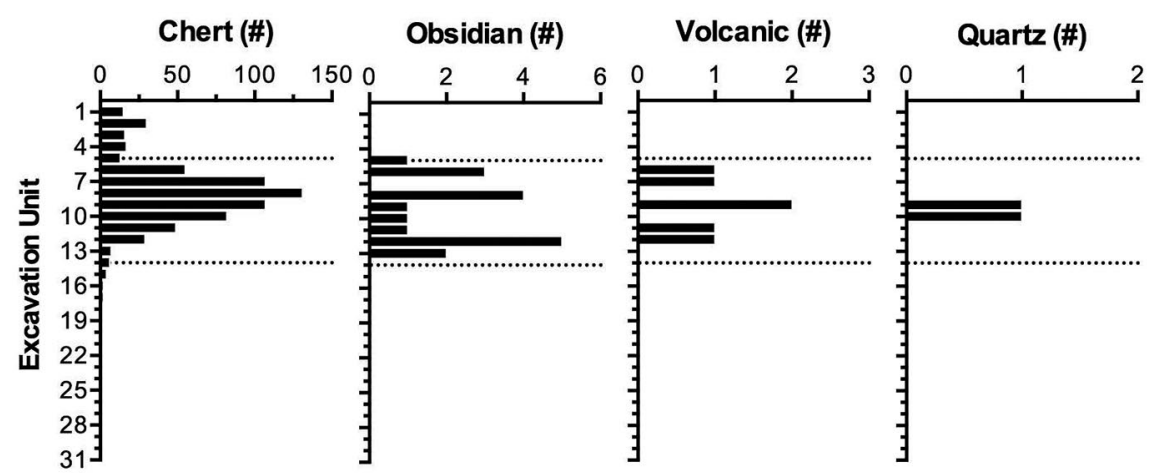

Chalcedony (\#)

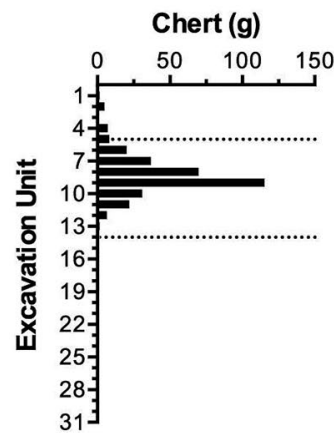

\section{Obsidian (g)}
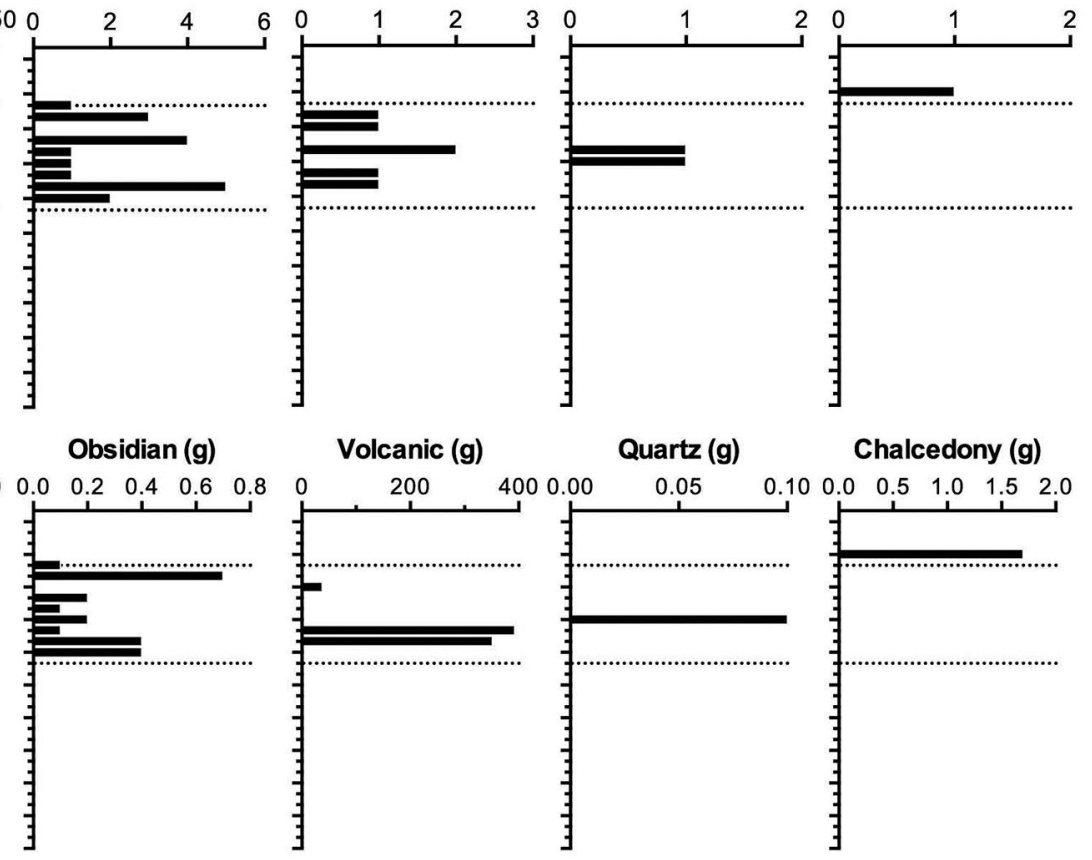

Chalcedony (g)

Figure 3.9. Vertical distribution of stone artefacts by raw material (by number and weight), Moiapu 3. The horizon between the dotted lines corresponds with su2. Source: Jerome Mialanes.

Table 3.5. Proportions of fracture types on chert artefacts, Moiapu 3.

\begin{tabular}{|l|r|r|}
\hline Fracture type & $\#$ & $\%$ \\
\hline Broken flake (other) & 403 & 60.0 \\
\hline Complete flake & 84 & 12.5 \\
\hline Flaked piece & 65 & 9.7 \\
\hline Proximal flake & 51 & 7.6 \\
\hline Distal flake & 39 & 5.8 \\
\hline Medial flake & 21 & 3.1 \\
\hline Potlid & 4 & 0.6 \\
\hline Bipolar core & 2 & 0.3 \\
\hline Left split cone & 1 & 0.1 \\
\hline Right split cone & 1 & 0.1 \\
\hline Unipolar core & 1 & 0.1 \\
\hline Total & $\mathbf{6 7 2}$ & 100 \\
\hline
\end{tabular}

Source: Authors' data.
In terms of fracture types, chert artefacts are mostly composed of broken flakes, complete flakes and flaked pieces (Table 3.5). Chert was mostly reduced using unipolar freehand percussion, with rare instances of bipolar percussion. The recovery of small flakes measuring less than $5 \mathrm{~mm}$ in both length and width indicates that stone knapping took place on-site. However, not all reduction stages took place within this part of the site. The rarity of cortex on the dorsal surfaces of flakes $(n=16$, 2.4 per cent) and on their striking platforms $(\mathrm{n}=1,1.5$ per cent) suggests that initial stages of reduction occurred elsewhere. Non-cortical unretouched complete flakes are small, with a mean weight of $0.5 \mathrm{~g}$ and a mean percussion length of $9.7 \mathrm{~mm}$. Complete flakes (excluding those $\leq 5.0 \mathrm{~mm}$ in length and width) exhibit one $(\mathrm{n}=15,40.5$ per cent), two $(\mathrm{n}=18$, 48.6 per cent), or three dorsal flake scars $(n=4$, 10.8 per cent). Based on the orientation of dorsal scars, most flakes show no evidence of core rotation $(n=21,56.8$ per cent), although evidence of a single core rotation was observed 
on 40.5 per cent ( $\mathrm{n}=15)$ of complete flakes (a further artefact ( 2.7 per cent of the assemblage) was non-diagnostic). Little care was taken during platform preparation, with overhang removal present on only 22 per cent $(n=18)$ of platforms.

A total of 18 obsidian artefacts were recovered from XU5 to XU13. Broken ( $\mathrm{n}=15,83.3$ per cent) and complete flakes ( $\mathrm{n}=3,16.7$ per cent) compose the entire assemblage. Thirteen obsidian artefacts (72.2 per cent) were analysed for provenance using portable X-Ray Fluorescence (pXRF); all were sourced to West Fergusson Island (Mialanes et al. 2016). Obsidian artefacts are all very small, averaging $0.14 \mathrm{~g}$ in weight and $7.7 \mathrm{~mm}$ in maximum length. No evidence of bipolar percussion is present on any obsidian artefact.

Among formal stone artefact types, retouched flakes make up 2.1 per cent $(n=15)$ of the total assemblage. Retouching was restricted to chert. Retouched chert flakes average $22.0 \mathrm{~mm}$ in percussion length, $17.7 \mathrm{~mm}$ in width and $6.0 \mathrm{~mm}$ in thickness. These are all rather squat artefacts with a mean elongation ratio of 1.2. The complete absence of retouched obsidian flakes suggests that they were used as-is, that they were too small to be retouched, or that they are simply byproducts of tool manufacture. The two complete obsidian flakes average $8.1 \mathrm{~mm}$ in percussion length, $6.0 \mathrm{~mm}$ in width, and are $1.1 \mathrm{~mm}$ and $1.8 \mathrm{~mm}$ in thickness respectively.

A flaked and ground axe/adze made from volcanic stone and weighing $392.3 \mathrm{~g}$ was also recovered from XU11. Two flakes found in XU6 and XU9 display a polished/ground surface, suggesting that they were produced on-site during axe/adze maintenance activities. A grinding stone $(351.4 \mathrm{~g})$ also made of volcanic rock was recovered from XU12, suggesting that grinding activities took place on-site. These volcanic artefacts were imports into Caution Bay, as the nearest major volcanic outcrops are located $80-100 \mathrm{~km}$ to the north-west and south-east of Port Moresby (Glaessner 1952; Pieters 1978; Smith and Milsom 1984). No volcanic outcrops occur at Caution Bay.

\section{Non-molluscan fauna}

The non-molluscan faunal assemblage includes two main categories of remains:

1. Vertebrate bone, including the remains of fish, reptiles including turtles, and mammals.

2. Cytoskeleton of invertebrates including exoskeleton of crustaceans (crabs and barnacles) and echinoderms (sea urchins).

A total weight was recorded for each of the major categories. Bone remains from each of the major taxonomic groups were weighed to a resolution of $0.01 \mathrm{~g}$. Any evidence of burning in the form of 'burnt' or 'calcined' bone was also recorded (see Aplin et al. 2016; Shipman et al. 1984). The taxonomic composition of fish and mammals is quantified as the number of identified specimens (NISP), except for scarid fishes where a series of isolated pharyngeal teeth from a single XU are counted as one identified element.

The total non-molluscan faunal assemblage comprises $94.6 \mathrm{~g}$ of vertebrate bone, $16.7 \mathrm{~g}$ of crab exoskeleton, $116 \mathrm{~g}$ of urchin exoskeleton, and $50.4 \mathrm{~g}$ of barnacle exoskeleton. Faunal remains are present in every XU from XU1 to XU20, with isolated tiny fragments of urchin exoskeleton recovered from XU22 and XU31. The vertical distribution of each major category of remains is summarised graphically for XU1 to XU20 in Figure 3.8. For all classes of remains there is a unimodal peak broadly spread across XU6-XU13 and with maximum values attained in XU9 or XU10. Only very small quantities of remains were recovered above XU6 or below XU13. The bone is predominantly unburnt (66 per cent overall; range for XU6 to XU13=47-78 per cent), with only 3 per cent overall of the burned bone being calcined (range for XU6 to XU13=010 per cent). 
The barnacle and urchin remains each appear to be monotypic- the urchin is identified as the Indo-Pacific collector urchin, Tripneustes gratilla. The barnacle is a robust-shelled acorn barnacle, with some of the remains representing individuals with original basal diameter of $15-20 \mathrm{~mm}$. The crab remains are highly fragmented and relatively few specimens can be determined taxonomically. The majority of recognisable fragments derive from members of the family Portunidae, including both 'sand-swimmer' morphs with elongate claws and robust-clawed mud crabs (Scylla serrata). Occasional fragments represent at least one other taxon, as yet undetermined even to family.

The vertebrate remains are dominated by terrestrial mammals (at least 39.1 per cent of the total assemblage; see Table 3.6), with lesser quantities of fish (17.4 per cent overall), marine turtle (0.9 per cent) and freshwater turtle (family Chelidae; 0.3 per cent overall). An 'unidentified' category accounts for 42.3 per cent of the bone by weight, but because fish bone is usually recognisable as such even when highly fragmented, based on its textural properties, the bulk of this category is likely to be also derived from terrestrial mammals.

Table 3.6. Vertical distribution (by weight) of the four major groups of vertebrates represented in the excavated remains, Moiapu 3.

\begin{tabular}{|c|c|c|c|c|c|c|}
\hline$X U$ & Fish & Marine turtle & $\begin{array}{l}\text { Freshwater } \\
\text { turtle }\end{array}$ & Mammal & Unidentified & Total bone \\
\hline 1 & - & - & - & - & - & - \\
\hline 2 & - & - & - & 0.28 & - & 0.28 \\
\hline 3 & - & - & - & - & - & - \\
\hline 4 & - & - & - & 0.06 & - & 0.06 \\
\hline 5 & - & - & - & 0.27 & - & 0.27 \\
\hline 6 & 1.09 & - & 0.18 & 0.09 & 4.70 & 6.06 \\
\hline 7 & 2.61 & - & 0.11 & 11.54 & 5.27 & 19.53 \\
\hline 8 & 1.74 & - & - & 0.55 & 6.11 & 8.40 \\
\hline 9 & 4.88 & 0.89 & - & 9.53 & 6.93 & 22.23 \\
\hline 10 & 3.01 & - & - & 5.84 & 8.89 & 17.74 \\
\hline 11 & 1.29 & - & - & 5.98 & 3.47 & 10.74 \\
\hline 12 & 0.87 & - & - & 2.37 & 3.45 & 6.69 \\
\hline 13 & 0.79 & - & - & 0.45 & 0.58 & 1.82 \\
\hline 14 & - & - & - & - & 0.46 & 0.46 \\
\hline 15 & - & - & - & - & 0.08 & 0.08 \\
\hline 16 & - & - & - & - & 0.05 & 0.05 \\
\hline 17 & - & - & - & - & - & - \\
\hline 18 & 0.21 & - & - & - & - & 0.21 \\
\hline Total & 16.49 & 0.89 & 0.29 & 36.96 & 39.99 & 94.62 \\
\hline
\end{tabular}

All values are in grams.

Source: Authors' data.

The fish bone includes representatives of at least six families (Table 3.7). Scaridae (parrot-fishes) and Labridae (wrasses) predominate, with Ariidae (fork-tailed catfishes) also well represented (recognisable from their lenticular otoliths as well as distinctively sculptured head plates). Balistidae (trigger fishes), Pomadyasidae (grunts and sweet-lips) and Tetraodontidae (puffer fishes) are each represented by single identified examples. Most of the scarid and labrid remains are from small to medium-sized fish (probably averaging $10-15 \mathrm{~cm}$ in length), but the remains of ariids and the single balistid are mainly from larger fish. 
Table 3.7. Vertical distribution of the six families of bony fishes identified in the excavated remains, Moiapu 3.

\begin{tabular}{|c|c|c|c|c|c|c|}
\hline $\mathrm{XU}$ & Ariidae & Balistidae & Labridae & Pomadyasidae & Scaridae & Tetraodontidae \\
\hline 1 & - & - & - & - & - & - \\
\hline 2 & - & - & - & - & - & - \\
\hline 3 & - & - & - & - & - & - \\
\hline 4 & - & - & - & - & - & - \\
\hline 5 & - & - & - & - & - & - \\
\hline 6 & 2 & - & - & - & 2 & 1 \\
\hline 7 & 2 & - & 3 & - & 5 & - \\
\hline 8 & 1 & - & 3 & 1 & 7 & - \\
\hline 9 & 1 & - & 6 & - & 8 & - \\
\hline 10 & 1 & - & 5 & - & 5 & - \\
\hline 11 & 1 & - & 1 & - & 3 & - \\
\hline 12 & - & - & - & - & 1 & - \\
\hline 13 & - & - & 3 & - & - & - \\
\hline 14 & - & - & - & - & - & - \\
\hline 15 & - & - & - & - & - & - \\
\hline 16 & - & - & - & - & - & - \\
\hline 17 & - & - & - & - & - & - \\
\hline 18 & - & 1 & - & - & - & - \\
\hline Total & 8 & 1 & 21 & 1 & 31 & 1 \\
\hline
\end{tabular}

All values are NISPS.

Source: Authors' data.

Both freshwater turtles and marine turtles are represented by small fragments of carapace and/or plastron (Table 3.6). The freshwater turtles (in XU6 and XU7) belong to the family Chelidae, of which several species are present in the streams and swamps of southern New Guinea. The marine turtle fragment in XU9 is distinguished primarily by its excessive thickness.

Table 3.8. Vertical distribution of the various terrestrial mammals identified in the excavated remains, Moiapu 3.

\begin{tabular}{|l|r|r|r|r|r|r|r|r|r|}
\hline XU & Peramelidae & $\begin{array}{c}\text { Macropus } \\
\text { agilis }\end{array}$ & $\begin{array}{l}\text { Dorcopsis } \\
\text { luctuosa }\end{array}$ & $\begin{array}{c}\text { Thylogale } \\
\text { brunii }\end{array}$ & $\begin{array}{c}\text { small } \\
\text { macropodid }\end{array}$ & $\begin{array}{c}\text { Melomys } \\
\text { sp. }\end{array}$ & $\begin{array}{c}\text { Rattus } \\
\text { gestroi }\end{array}$ & $\begin{array}{c}\text { Small } \\
\text { murid }\end{array}$ & $\begin{array}{c}\text { Sus } \\
\text { scrofa }\end{array}$ \\
\hline 1 & - & - & - & - & - & - & - & - & - \\
\hline 2 & - & - & - & - & - & - & - & - & - \\
\hline 3 & - & - & - & - & - & - & - & - & - \\
\hline 4 & - & - & - & - & - & - & - & - & - \\
\hline 5 & - & - & - & - & - & - & - & - & 1 \\
\hline 6 & - & & - & - & - & - & - & - & 1 \\
\hline 7 & - & 3 & - & - & - & - & - & - & 2 \\
\hline 8 & - & - & - & - & - & - & - & - & 3 \\
\hline 9 & - & - & - & 2 & - & - & - & - & 8 \\
\hline 10 & - & - & 1 & - & 1 & 1 & - & 1 & 4 \\
\hline 11 & 1 & - & - & - & - & - & 1 & 1 & 1 \\
\hline 12 & - & - & - & - & 1 & - & - & 1 & - \\
\hline 13 & - & - & - & 2 & - & - & - & - & - \\
\hline Total & 1 & 3 & 1 & 4 & 2 & 1 & 1 & 3 & 20 \\
\hline
\end{tabular}

All values are NISPS.

Source: Authors' data. 
The small number of identified mammal remains include representatives of four families: Peramelidae (bandicoots), Macropodidae (wallabies), Muridae (rats and mice) and Suidae (pigs) (see Table 3.8). Pigs are consistently represented in the larger samples of bone derived from XU5 to XU11, and the remains clearly derive from multiple individuals based on stages of tooth eruption and wear. Also represented are the agile wallaby (Macropus agilis) and two forestdwelling smaller wallabies (species of Dorcopsis and Thylogale).

\section{Molluscan shell}

Marine shells totalling $14.7 \mathrm{~kg}$ were recovered in varying quantities from most of the $31 \mathrm{XUs}$, with the majority of discarded mollusc food remains coming from XU5 to XU13. The average shell mass in these core XUs is approximately $1.6 \mathrm{~kg}$ per XU (range 212-2922 g/XU). Relatively small amounts of shell $(0-100 \mathrm{~g} / \mathrm{XU})$ were collected from other XUs. The sparse amount of shell found below XU18 is most likely the consequence of taphonomic processes, such as trampling or bioturbation, or may be the result of random discard events (e.g. XU30 contains only one broken piece of spider conch shell).

In total 74 per cent of all shell by weight was identified to family, genus or species level. This comprises 24 marine bivalve taxa (4168.4 g, 28 per cent) and 44 marine gastropod taxa $(6694.0 \mathrm{~g}$, 46 per cent), with one freshwater bivalve species (Batissa violacea) and one freshwater gastropod species (Theodoxus fluviatilis). A total of $3805.7 \mathrm{~g}$ of shell could not be identified.

The 10 most abundant taxa by minimum number of individuals (MNI) account for 92 per cent of the total assemblage: Cerithideopsis largillierti $(\mathrm{MNI}=2806,79$ per cent), Ostreidae (MNI=431, 10 per cent), Conomurex lubuanus (MNI=191, 5 per cent), Canarium spp. (MNI=163, 5 per cent), Pinctada sp. (MNI=93, 3 per cent), Dolabella auricularia (MNI=85, 2 per cent), Bulla ampulla (MNI=47, 1 per cent), Nerita planospira (MNI=45, 1 per cent), Hemitoma spp. $<10 \mathrm{~mm}$ (MNI=43, 1 per cent) and Anodontia edentula (MNI=31, 1 per cent).

Mangrove species (70 per cent) are dominant, followed by intertidal rocky substrate species and species that inhabit seagrass beds (Figure 3.10). Predominant taxa range significantly in size and meat weights, from $\leq 1 \mathrm{~g}$ per individual (e.g. Cerithideopsis largillierti, Nerita planospira) to $35 \mathrm{~g}$ (e.g. Lambis lambis) (Bird et al. 2002:462; Thomas 2002:198). A Conomurex lubuanus specimen contains on average $2 \mathrm{~g}$ of edible meat, and Canarium spp. molluscs contain c. $1 \mathrm{~g} /$ specimen (Thomas 2001:83; Szabó 2011). Despite the small meat weight per specimen, the sheer numbers of Cerithideopsis largillierti throughout the cultural deposit suggest that they were of importance, be it for their reliability or large numbers. Small quantities of Polyplacophora (chiton, $0.5 \mathrm{~g}$ ), Vermetidae (wormtube, $3.1 \mathrm{~g}$ ), Camaenidae and Subulinidae (both land snail families, $2.1 \mathrm{~g}$ ) were also distributed throughout the sequence.

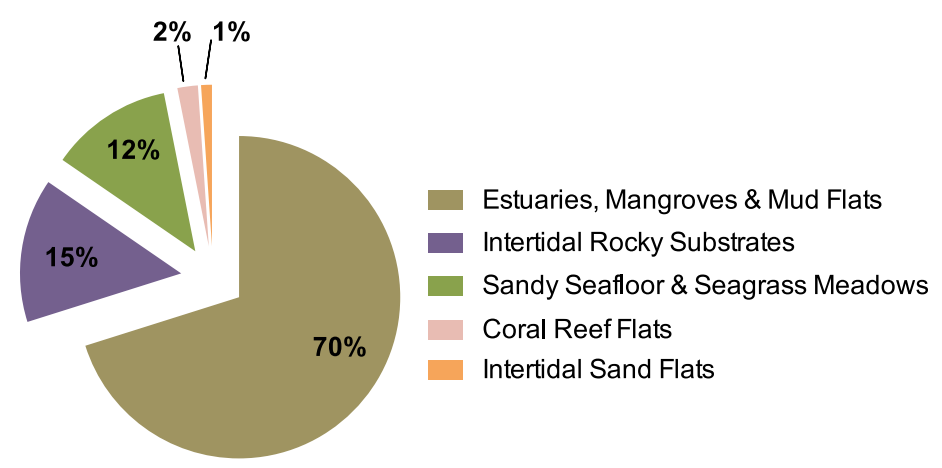

Figure 3.10. Percentages of marine shell taxa by habitat, based on MNI, Moiapu 3.

Source: Authors' data. 


\section{Worked shell}

Two pieces of worked shell were identified from within the molluscan assemblage, with one being a broken formal artefact and the other an expedient tool. The formal artefact is a fragment of a Conus sp. ring and was recovered from XU7 (Figure 3.11a). The original ring would have had an internal diameter of c. $6 \mathrm{~cm}$ and can be considered a 'broad ring' with a width of $25.6 \mathrm{~mm}$. The edges are slightly weathered and an old break along much of the length of the fragment could have been the breakage that prompted discard. Surface weathering, potentially combined with wear, has removed any surface patterning, meaning that the species used for its manufacture can no longer be identified. However, the size suggests that it was manufactured from a large species of Conus such as C. litteratus or C. leopardus.

The second piece of worked shell also derives from XU7. It is a body and ventral margin fragment of a valve of the large, robust estuarine bivalve Polymesoda erosa (Figure 3.11b). A series of retouch scars initiated from the outer surface of the valve is apparent along the ventral margin and, despite the post-depositional weathering apparent on much of the extent of the surface and edges, zones of polish on elevated surfaces can still be seen (Figure 3.11c). P. erosa and other large species within the Corbiculidae are frequently recorded as unmodified expedient tools within regional ethnographies (e.g. Fox 1970; Roth 1904), but deliberate retouch is less frequently noted and is also generally uncommon within archaeological assemblages (Szabó personal observation). Whether the retouch on the Moiapu 3 artefact is related to the original creation of the artefact or rejuvenation after the blunting of the naturally sharp ventral margin through use is unclear.
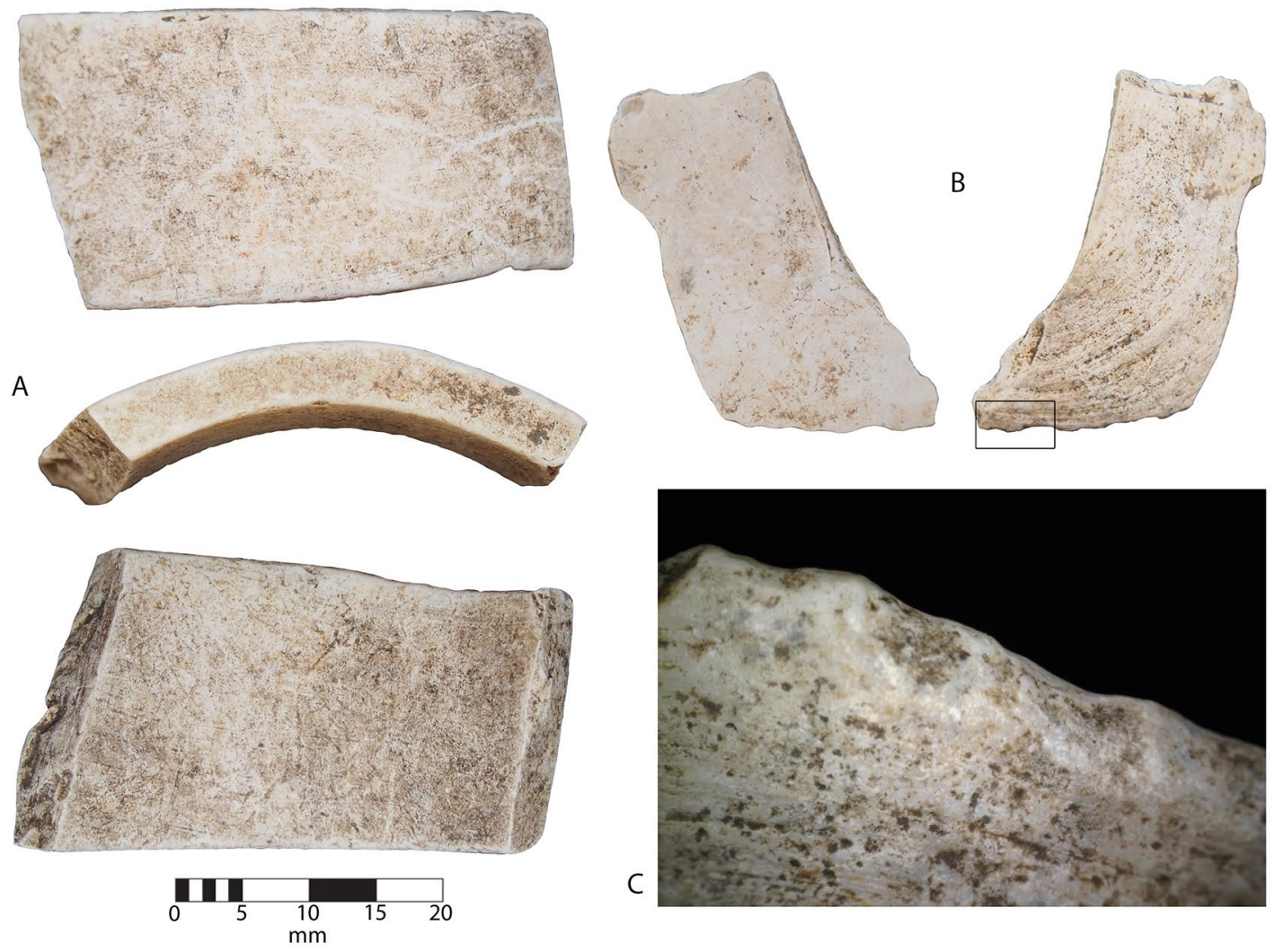

Figure 3.11. Worked shell from Moiapu 3, XU7. (A) Conus sp. broad ring fragment. (B) Retouched and utilised Polymesoda erosa valve fragment. (C) Detail of utilised margin of $P$. erosa tool magnified $40 \geq$. Source: Photos by Brent Koppel. 


\section{Ceramic sherds}

A total of 8801 pottery sherds $\geq 2.1 \mathrm{~mm}$ wide (the size of the sieve mesh), weighing $3.16 \mathrm{~kg}$, were excavated from Moiapu 3. Eighty-five of these sherds are $\geq 3 \mathrm{~cm}$ long (range $=30.0-90.6 \mathrm{~mm}$ ), which, together with a further 33 decorated and/or rim sherds $<3 \mathrm{~cm}$ long, make up the diagnostic assemblage. Just one sherd has a manufacturing mark, being a sherd with a paddle groove on the external rim surface. Nine (11 per cent) of the 85 sherds $\geq 3 \mathrm{~cm}$ long are red-slipped (the red-slipped sherds $<3 \mathrm{~cm}$ long were not counted). Here we present details of all body and lip decorations other than red slip, and vessel shapes.

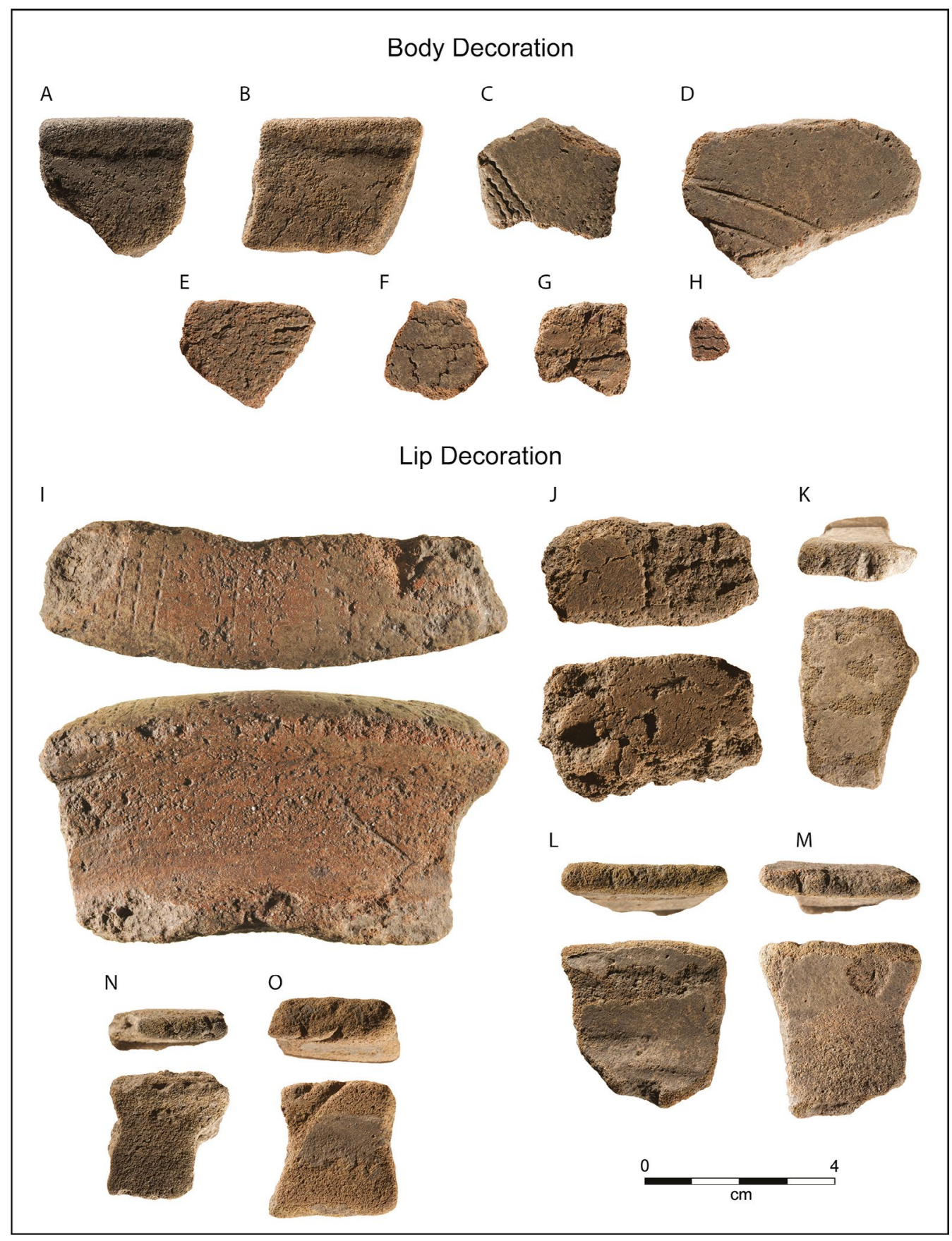

Figure 3.12. Decorated sherds from Moiapu 3.

Source: Photos by Steve Morton. 


\section{Body decoration}

Eight sherds (four are $\geq 3 \mathrm{~cm}$ long, four $<3 \mathrm{~cm}$ long) exhibit body decoration other than red slip. One sherd has two parallel incisions slightly curving along the width of the sherd, suggesting that it was incised with a two-tined (or multi-tined) tool (Figure 3.12d). Seven sherds have single (Figure 3.12g), parallel (Figures 3.12a, 3.12b, 3.12c, 3.12e and 3.12h) or parallel and converging (Figure 3.12f) wavy lines impressed with the lip of a shell valve. Two of these sherds (Figures 3.12a and 3.12b) conjoin and have a slight wide depression (not quite marked enough to call a 'finger groove') along the base of the outer part of the lip.

\section{Lip decoration}

Seven sherds have decorated lips. One has eight parallel dentate-stamped lines across its curved, wide lip (Figure 3.12i). A second, poorly preserved sherd has one dentate-stamped line on top of a flatter lip (Figure 3.12j). Given the major difference of the curvature at the top of the lip, it is unlikely, although not impossible, that the two sherds came from the same vessel. Five sherds have notched lips, three of which have the notches on top (Figures $3.12 \mathrm{k}-3.12 \mathrm{~m}$ ) and the other two along the outer edge of the lip (Figures 3.12n and 3.12o). No sherd possesses both body and lip decoration.

\section{Vessel form}

There are in total 63 rim sherds ( 32 are $\geq 3 \mathrm{~cm}$ long, $31<3 \mathrm{~cm}$ long), only nine of which are large enough to reveal details of vessel form. Here we label a vessel with an orifice diameter greater than the vessel depth a 'dish'; a vessel with an approximately equal orifice diameter and vessel depth a 'bowl'; and a vessel with an orifice diameter smaller than the vessel's maximum depth a 'pot'. Four of the nine diagnostic rim sherds are from everted indirect pots with necks, one is from an inverted bowl, three are from everted dishes or bowls (indeterminate), and one is from an inverted dish or bowl (this sherd is not large enough to determine shape). One sherd from an everted indirect pot has an orifice diameter that measures $26 \mathrm{~cm}$; two conjoining everted sherds are from a dish or bowl with an orifice diameter measuring $34 \mathrm{~cm}$. The four everted pots with necks have rims that are 2.2, 2.6, 2.9 and $3.3 \mathrm{~cm}$ long.

The small sample size and generally high levels of fragmentation allow for no more than general comments about vessel morphology. The lip profiles of the sherds from everted dishes or bowls are all flat, whereas those from inverted dishes or bowls are all externally swelling. Two sherds from the everted indirect pots with necks have rounded lips, one has a flat lip, and one lip is externally and internally swelling. For all 63 rim sherds of any size, 27 (44 per cent) have rounded lip profiles, 24 (39 per cent) are flat, four (6 per cent) are externally swelling, three (5 per cent) are externally tapering, three ( 5 per cent) are internally and externally swelling, and one is bevelled (1 per cent). Comparing the lip profiles of the nine sherds analysed to vessel form with those of the 63 rim sherds from the full assemblage suggests that sherds from everted vessels make up the bulk of the Moiapu 3 assemblage, with sherds from inverted vessels rare by comparison. There are no signs of carinations in the assemblage.

\section{Discussion}

The chronologically well-defined cultural horizon at Moiapu 3 is of particular interest in regard to questions of regional occupation and cultural change because it enables us to better determine what happened at the end of the identifiably Lapita phase at Caution Bay. If, in the first instance, we identify Lapita as a purely archaeological phenomenon recognisable by tell-tale 
signs of material culture, in particular the defining dentate-stamped ceramics, we can then situate temporal trends in ceramics within broader trends in the material culture of the Lapita Cultural Complex. In other words, how do dentate-stamped ceramics transform in relation to other aspects of material culture and site occupation, and what are the implications of those dynamics for social and cultural behaviour through time?

Moiapu 3's ceramic assemblage is characterised by a small number of decorated sherds, in particular body decoration consisting of wavy lines impressed with the margin of a shell valve. This is a rare form of decoration in Caution Bay typically seen at the end of the Lapita phase-as it is also in the Kouri lowlands $230 \mathrm{~km}$ to the north-west (Skelly and David 2017)—although it is only now that we have managed to put a firm date on its antiquity (because of its rarity). Shell impressions of this kind occur on Late Lapita ceramics elsewhere in Island Melanesia (e.g. Bedford 2015:30; Kirch 1997:155; Summerhayes 2000:233), but by themselves do not readily define a 'Lapita' assemblage (because such decorations can occasionally be found in much later assemblages also). At Caution Bay they better characterise the very terminal end of Lapita, just at a time when dentate stamping ceases, a similar scenario to that found across the Lapita distribution. It is of interest that lip decorations on ceramics do include dentate stamping at Moiapu 3, the two dentate-stamped lips recovered at this site representing the last examples of dentate stamping identified at Caution Bay.

Dentate stamping does not occur on any of the 14454 sherds analysed so far from excavation Squares A and B of the nearby site of Moiapu 2, located $15 \mathrm{~m}$ to the north of Moiapu 3 and dating largely to within the period c. 2500-2400 cal. BP (as surface archaeological exposures, Moiapu 2 and Moiapu 3 are different archaeological sites, but sub-surface they are almost certainly different parts of the same village whose spatial extent shifted slightly through time). Nor do any dentate-stamped ceramics occur among the 13553 sherds excavated from Tanamu 2, located $2 \mathrm{~km}$ north-west of Moiapu 3 and largely dating to within the period 2480-2400 cal. BP. Dentatestamped ceramics do occur, however, $2.1 \mathrm{~km}$ north-west of Moiapu 3 at Tanamu 1 between 2800-2750 cal. BP; $2.2 \mathrm{~km}$ north-west of Moiapu 3 at Bogi 1 between 2900-2600 cal. BP; and $700 \mathrm{~m}$ south-east of Moiapu 3 at Edubu 1 Square A around or very shortly after a median age of $2580 \mathrm{cal}$. BP (unpublished data in authors' possession, updating the chronology presented in David et al. 2011; McNiven et al. 2011, 2012).

More than 50000 sherds have been analysed so far from the sum of these assemblages, suggesting that the overall pattern is meaningful of the broader regional trend. At Caution Bay, dentate-stamped ceramics repeatedly occur within sites between c. 2900 cal. BP (Bogi 1) and c. $2580 \mathrm{cal}$. BP (Edubu 1), with the latest example coming from Moiapu 3 sometime between 2630-2410 cal. BP-and most probably c. $2550 \mathrm{cal}$. BP-in the form of two lip-decorated sherds, just as wavy lines impressed with the lip of a shell valve begin to appear as body decoration (wavy lines impressed with shell valves are also found at Edubu 1 at approximately the same time as at Moiapu 3). We note that the shell valve wavy lines appear to be a very short-lived phenomenon on Caution Bay ceramics, for by $2500 \mathrm{cal}$. BP all forms of body decoration had disappeared entirely, as evident by the plain body ware ceramics of Moiapu 2 and Tanamu 2 that date largely to the period commencing c. $2500 \mathrm{cal}$. BP (note also that the shell indentations of the Linear Shell End-Impressed Tradition are a formally different phenomenon that begins at Caution Bay about 300 years after shell valve wavy lines cease to appear on ceramics; see David et al. 2012).

The span of time over which dentate stamping ceased at Caution Bay is sudden, taking place over no more than a few decades (probably less than 50 years), if we take Bogi 1 (c. 2600 cal. BP) and Edubu 1 (c. $2580 \mathrm{cal}$. BP) as their most recent common expressions within site assemblages and Moiapu 3 as the timing of their last throes. All forms of carination also suddenly stop, the 
more recent examples dating to $2600 \mathrm{cal}$. BP at Bogi 1 . Yet the villages continued to exist across Caution Bay, often in their same general locations as before. So too do forms of lip decoration continue to be applied to ceramics, in particular shallow notches across the tops of lips and along their inner or outer edges, continuing for hundreds of years after the cessation of dentate stamping. It is not just in Moiapu 3's ceramics that we find evidence of change with continuity at Caution Bay, but in other aspects of material behaviour also, as discussed below.

\section{Fauna}

The faunal assemblage from Moiapu 3 is here compared with assemblages from three other sites in the Caution Bay landscape: the contemporaneous terminal Lapita site of Edubu 1 (McNiven et al. 2012); Ruisasi 1, which dates to 1603-1402 cal. BP (David et al. 2016), and Tanamu 1, which produced three major assemblages dating to the periods c. 4350-4050 cal. BP (aceramic 'Pre-Lapita'), c. 2800-2750 cal. BP ('Lapita') and c. 200-100 cal. BP ('historic') (Aplin and Frost forthcoming). Four topics relating to the fauna at the very end of the Lapita period, as represented by Moiapu 3 in relation to other Caution Bay sites, warrant brief consideration: 1) the exploitation of molluscs; 2) the exploitation of sea urchins; 3) the balance of marine vs terrestrial vertebrates; and 4) the occurrence of $\operatorname{dog}$ and pig remains.

\section{Molluscs}

The bulk of mollusc remains recovered from Caution Bay excavations date to the Post-Lapita occupation period. The dominant species by MNI during the terminal Lapita phase (data from the following sites: Ataga 1, Edubu 1, Moiapu 2, Moiapu 3, Nese 1, Tanamu 1, Tanamu 2 and Tanamu 3) are Cerithideopsis largillierti followed by Conomurex luhuanus, Canarium spp., Ostreidae and Gafrarium spp. On average, these dense deposits consist of almost $20 \mathrm{~kg}$ of discarded marine molluscs each. At Tanamu 1, however, the densest concentrations of marine molluscs occur in the pre-ceramic and Lapita horizons, with over 90 mollusc species represented in the pre-ceramic horizon and over 60 mollusc species represented in the Lapita horizon.

An analysis of the trends in shellfish habitat utilisation indicates that the peoples of Caution Bay exploited a broad range of tidal habitats with different substrates - sand, rocks, mud, coral reefs, seagrass beds and mangroves. However, not all these habitats were equally targeted. In the earliest phases of occupation at Caution Bay, during pre-ceramic and Lapita phases, sandy mudflat habitats were particularly targeted for shellfish subsistence. A transition to sandy seagrass habitats during the terminal Lapita phase followed by estuarine mangrove environments is evident, which may relate to changes in prograding shorelines and the creation of more extensive sandy to muddy intertidal and subtidal environments.

\section{Sea urchins}

The relative prevalence of urchin remains in Moiapu 3 (equivalent to 1 per cent of the molluscan shell weight) is precisely mirrored in the Ruisasi 1 assemblage dating some 1000 years later (David et al. 2016). The Edubu 1 assemblage that is approximately contemporaneous with Moiapu 3 contains even larger quantities of urchin (equivalent to 7 per cent of the molluscan shell weight; McNiven et al. 2012). By contrast, very small quantities of urchin are present in each of the three Tanamu 1 assemblages (Pre-Lapita, Lapita and 'historic' phases; Aplin and Frost, forthcoming), none of which are contemporaneous with Moiapu 3. In each site the urchin remains represent a single species - the widespread Indo-Pacific collector urchin (Tripneustes gratilla) — which Pernetta and Hill (1981:178; see also Nojima and Mukai 1985) reported to be 'common on reef flat areas and in sea grass beds, wherever these occur along the coast' and also 
noted that it 'appears to have been widely used for food'. The highest food value of urchins is in the gonads, especially in the roe or 'uni' of females, which can weigh 10-15 g in a mature animal. However, the gut and quiescent reproductive tract can be consumed at any time. In tropical regions reproduction in T. gratilla appears to be more or less continuous through the year, though it follows a monthly spawning rhythm modulated by lunar cycles (Chen and Chang 1981).

The abundance of urchin remains in two assemblages dated between c. $2550 \mathrm{cal}$. BP and $1500 \mathrm{cal}$. BP (Moiapu 3 and Ruisasi 1, respectively) points to a sustained pattern of exploitation of this species, spanning at least one full millennium. Remarkably, given its former abundance, a marine survey in 2007-2008 failed to detect the Indo-Pacific collector urchin within Caution Bay (Coffey Natural Systems 2009). The fact that the Indo-Pacific collector urchin is scarce in the 'historical' assemblage from Tanamu 1, coupled with the wider regional evidence for its economic exploitation (Pernetta and Hill 1981), suggests that it had declined locally sometime prior to the European-contact period.

Intensity of urchin discard mirrors the trend for peak discard of shellfish occupying the same coral reef flats and sandy seafloor and seagrass meadow habitats, dominated by Conomurex luhuanus, Lambis spp. Canarium labaitum and Laevistrombus canarium (Figure 3.13). This indicates focused exploitation of this habitat during the terminal Lapita period. However, it is unclear whether the shellfish or urchin were the primary suite of taxa targeted, or whether collection of both was part of a continuation of a broad-based subsistence strategy that characterised all periods of Caution Bay shellfish exploitation (see Szabó and Anderson (2012) and Szabó et al. (2012) for comparisons of fluctuating shellfish and urchin remains at the Tangarutu site, Rapa Island further to the east in Polynesia).

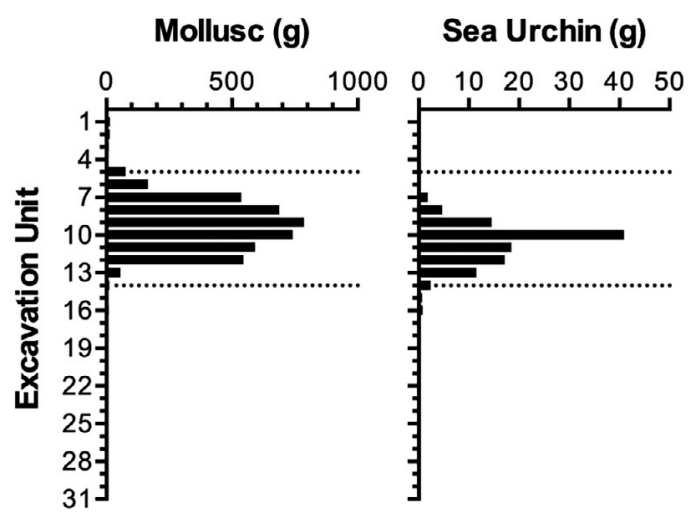

Figure 3.13. Abundance of sea urchin versus mollusc from sea urchin habitats (coral reef flats, sandy seafloor and seagrass meadows), Moiapu 3.

The horizon between the dotted lines corresponds with SU2.

Source: Authors' data.

\section{Marine vs terrestrial vertebrates}

The Moiapu 3 vertebrate fauna is dominated by the remains of terrestrial mammals and the marine component is almost exclusively comprised of fish bone. Among the other assemblages analysed to date, this pattern most closely matches that of the 'historic' sample from Tanamu 1 (Figure 3.14). However, there is also a broad similarity between these assemblages and those from the terminal Lapita site of Edubu 1 and from the Lapita horizon of Tanamu 1 (the small size of the Moiapu 3 excavation notwithstanding), both of which have less than 22 per cent by weight contributed from marine taxa (Aplin and Frost forthcoming; McNiven et al. 2012). In each of these assemblages, squamate reptiles and turtles (both freshwater and marine) are slightly better represented, thus giving an overall impression of higher diversity. However, to some extent this impression may be a product of the larger quantities of remains recovered from each of Tanamu 1 and Edubu 1. 
$\%$ Freshwater Turtle
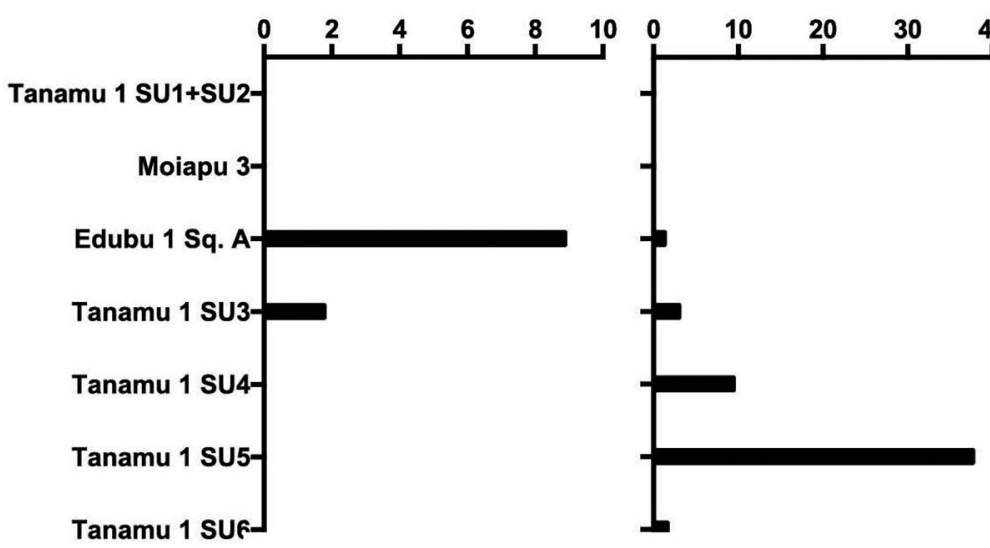

$\%$ Dugong

$\%$ Land Mammals (incl. unidentified)

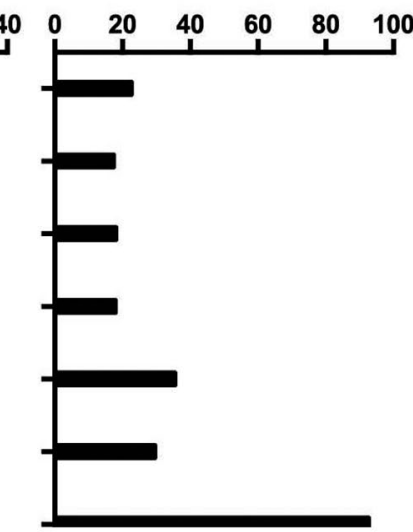

$\%$ Squamates

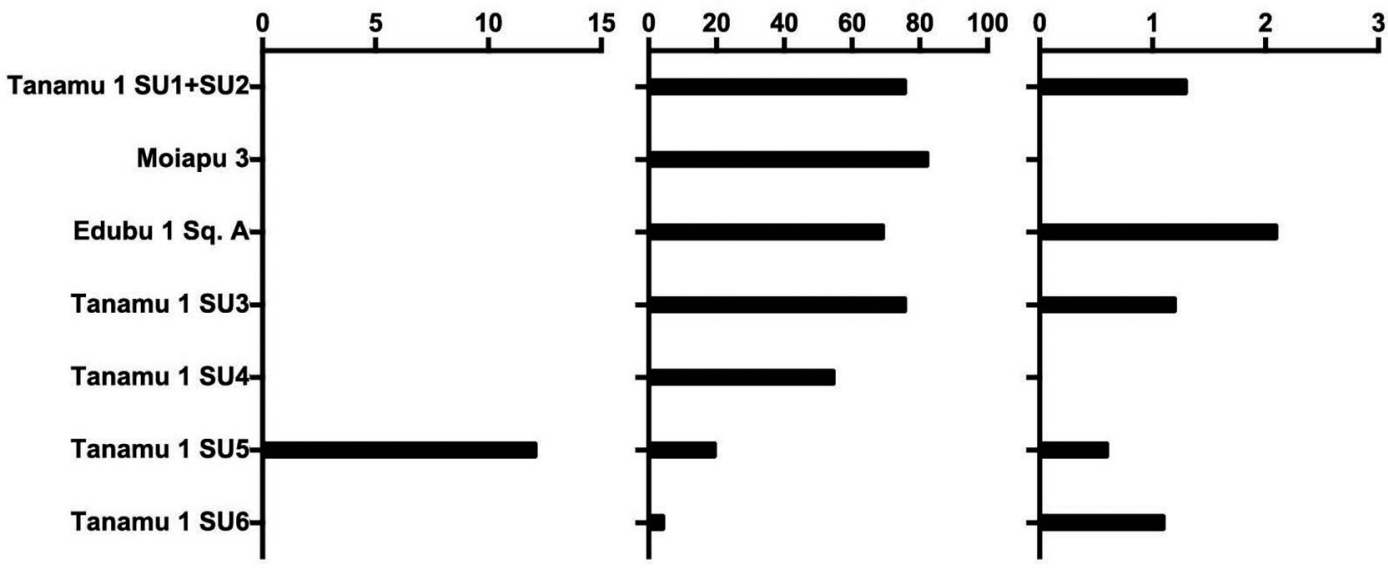

Figure 3.14. Taxonomic composition of the vertebrate faunal remains in each of seven Caution Bay assemblages of varying antiquity including pre-ceramic (Tanamu 1 SU6 to SU4), Early Lapita period (Tanamu 1 SU3), terminal Lapita period (Edubu 1), immediately Post-Lapita (Moiapu 3) and 'historic' period (Tanamu 1 SU1 to SU2).

The plotted percentages are the contribution of each of the major taxa to the total bone weight.

Source: Authors' data.

The Caution Bay non-molluscan assemblages analysed to date point to an essential continuity in the pattern of economic activities, from Lapita times through to the 'historic' period. McNiven et al. (2012) reported for the terminal Lapita site of Edubu 1 that this pattern involved broadbased exploitation of many different terrestrial and marine resources, with the terrestrial resources drawn from a landscape already significantly transformed through conversion of the original monsoonal forest cover into a mosaic of forest, savannah woodland and/or grassland, presumably under an extractive regime that involved regular use of fire. The larger non-molluscan faunal assemblage from the slightly older Lapita horizon at Tanamu 1 (Aplin and Frost forthcoming) confirms their general characterisation and pushes the age of this landscape and associated extractive pattern back at least to $2800 \mathrm{cal}$. BP. Exactly how much earlier this pattern of activities commenced will only become clear after analysis of additional assemblages that date from PreLapita times at Caution Bay. At present the only insight into this period comes from the lower levels of Tanamu 1, but the strong emphasis on marine resources at this time provides few clues as to what was taking place in the terrestrial sphere. 
The dominant continuity in faunal assemblages since $2800 \mathrm{cal}$. BP is overprinted by a number of seemingly subtle changes, some of which may have had significant economic and social ramifications. One such change is the apparent early decline, during the Lapita period, of the larger marine animals (turtles and dugongs), presumably due to over-exploitation and/or changes in near-shore habitats. Large animals are unusual resources insofar as their procurement creates a short-term oversupply of meat. For this reason, they represent a particular impetus for food sharing, which in turn is a key component of the social lexicon of food procurers and producers (Gurven 2004).

\section{Pigs and dogs}

Another change that occurs somewhere within the time frame under consideration here is the introduction to the Caution Bay area of the pig and the dog. The importance of both of these exotic species needs little introduction. Pigs are not only pivotal as domestic animals in the socioeconomic systems of many New Guinean societies, but as feral animals they also feature prominently in the ecology of various habitats ranging from lowland savannah and alluvial forest to subalpine scrub and grassland, and in the livelihoods of people who now hunt them in these contexts (Hide 2003). Dogs also perform important roles as domestic animals, including personal and village security, and as essential adjuncts in most hunting activities. The distribution and impact of feral dog populations in New Guinea is not well understood, but as the apex predator they presumably play a key role in population regulation of their prey species.

The debate about exactly when pigs and dogs first came to New Guinea has for a long time involved competing 'short' and 'long' chronologies. The 'long' postulates an earlier arrival of pigs in New Guinea, possibly during the early to mid-Holocene, with a potentially later arrival of dogs (Allen 2000; Bulmer 1966, 1975, 1982; Golson 1991; White and O'Connell 1982). The 'short' chronology links the arrival of pigs and dogs in New Guinea with the wider process of 'Austronesian expansion' from Southeast Asia into Island Melanesia, commencing c. 3300 cal. BP (e.g. Bellwood 1985; O’Connor et al. 2011; Spriggs 1996).

The Caution Bay archaeological complex offers great potential for refinement of the timing of the introduction of pigs and dogs, at least to the local region. Many sites, such as Edubu 1 (McNiven et al. 2012) and Moiapu 3 described here, accumulated rapidly (usually over periods of a few decades to less than two centuries) and were not subsequently reoccupied; hence, the excavated assemblages are unlikely to represent palimpsests.

Pig and dog are present in small but consistent quantities throughout the main cultural horizon in each of Edubu 1 (McNiven et al. 2012) and Moiapu 3, as reported here. By contrast, pig alone is present in the Lapita horizon at Tanamu 1 and the remains are few in number and restricted to the uppermost levels of the dense cultural horizon, close to where it comes into contact with culturally sparse and more mixed overlying deposits. Until better evidence is found for either pigs or dogs in any clearly Lapita context (as opposed to very terminal Lapita), we are inclined to regard their scarcity in this assemblage as evidence of absence from the Caution Bay landscape at that time. Dogs, in their likely primary role as companion animals rather than as a food resource, are less likely to be represented in all refuse contexts, and their occurrence is more likely to evade archaeological detection. Nevertheless, the contrast in the frequency of their remains in the Caution Bay sites before and after c. $2550 \mathrm{cal}$. BP is striking and compels us to date the arrival of both pigs and dogs to the period between $2750 \mathrm{cal}$. BP (timing of the end of Lapita-period occupation at Tanamu 1) and c. 2550 cal. BP (timing of occupation at Edubu 1 and Moiapu 3). The arrival of pigs and dogs occurs either shortly before or coincident with the last use of diagnostically Lapita ceramics at Caution Bay, dated to c. 2600 cal. BP at Bogi 1, c. $2580 \mathrm{cal} . \mathrm{BP}$ at Edubu 1, and c. $2550 \mathrm{cal}$. BP at Moiapu 3. 
What might have caused an end to the long-lived and symbolically charged cultural practice of dentate stamping of ceramics (e.g. see Burley 2007; Sheppard et al. 2009; Spriggs and Bedford 2013)? A period of social disruption and the breakdown of social networks at various scales is certainly one obvious possibility, and the arrival of pigs and dogs in the area might well have triggered rapid ideological and socioeconomic change on a scale that could lead to social disruption (cf. Dwyer and Minnegal 1992). On the other hand, there is strong evidence from other aspects of the ceramics and from the wider archaeological record of Caution Bay, including the economic refuse, for continuity rather than disruption. To reconcile these seemingly disparate observations, we posit that the arrival/introduction of two new animals with unprecedented socioeconomic potentialities triggered off a period of rapid social readjustment and cultural transformation at Caution Bay, and perhaps more widely along the south coast of PNG. The outcome was most likely variable-where the new challenges could not be met, disruption probably ensued, but where they were met with accommodation and both social and technological innovation, the results were very likely positive. Typically, during such periods of rapid change and innovation in history, the cultural lexicon and its associated symbolism are deconstructed and rebuilt. Symbols of formerly great cultural significance can lose their meaning, even though the fundamental property with which they were associated carries on unaffected (such shifts in meaning are at the core of Derrida's (1968) notion of 'différance'; see also David 2002:67-88). New meanings can become attached to old symbols, and entirely new forms of symbolism can emerge. Some of the 'old' is often forgotten in the excitement of discovering the 'new'. In our view, the decline and eventual cessation of the long-standing practice of dentate-stamped/carinated ceramics at Caution Bay might well be explained in such terms - as a loss of symbolism (and thus of reason to continue with the practice) during a period of intensive socioeconomic readjustment and innovation. At the same time, new symbols of social identity and connectivity may well have emerged, and the pig itself, as a potentially communal asset and food resource, may have taken on certain functions in already-connected communities, paving the way for new processes of connection and intensification.

\section{Acknowledgements}

We thank Namona Seri from Boera village, Clara Numbasa and Suzanna Montana for helping with the excavations, and Jane Lavers for assistance with preliminary identifications of the molluscan assemblage. Bruno David thanks the Australian Research Council (ARC) for Discovery grants and QEII and DORA Fellowships DP0877782 and DP130102514. Sean Ulm is the recipient of an Australian Research Council Future Fellowship (project number FT120100656). We also thank the ARC Centre of Excellence for Australian Biodiversity and Heritage under whose auspices much of this work was undertaken. Thanks to Lynden McGregor of Geomatix for the original draft of Figure 3.3 and Kara Rasmanis for drafting Figures 3.1, 3.2 and 3.5.

\section{References}

Allen, J. 2000. From beach to beach: The development of maritime economies in prehistoric Melanesia. In S. O'Connor and P. Veth (eds), East of Wallace's Line: Studies of past and present maritime cultures of the Indo-Pacific region, pp. 139-176. Modern Quaternary Research in Southeast Asia 16. A.A. Balkema, Rotterdam.

Aplin, K. and A. Frost forthcoming. The non-molluscan faunal remains from Tanamu 1. In B. David, T. Richards, K. Aplin, I.J. McNiven and M. Leavesley (eds), Lapita to Post-Lapita transformations at Caution Bay: Cultural developments along the South Coast of mainland Papua New Guinea. Archaeopress, Oxford. 
Aplin, K., T. Manne and V. Attenbrow 2016. Using a 3-stage burning categorization to assess postdepositional degradation of archaeofaunal assemblages: Some observations based on multiple prehistoric sites in Australasia. Journal of Archaeological Science: Reports 7:700-714. doi.org/10.1016/j.jasrep.2015. 11.029 .

Bedford, S. 2015. Going beyond the known world 3000 years ago: Lapita exploration and colonization of Remote Oceania. In C. Sand, S. Chiu and N. Hogg (eds), The Lapita Cultural Complex in time and space: Expansion routes, chronologies and typologies, pp. 25-47. Archeologia Pasifika 4. Institut d'archéologie de la Nouvelle-Calédonie et du Pacifique (IANCP), Nouméa.

Bellwood, P. 1985. Prehistory of the Indo-Malaysian archipelago. University of Hawai'i Press, Honolulu.

Bird, D.W., J.L. Richardson, P.M. Veth and A.J. Barham 2002. Explaining shellfish variability in middens on the Meriam Islands, Torres Strait, Australia. Journal of Archaeological Science 29(5):457-469. doi.org/ 10.1006/jasc.2001.0734.

Bronk Ramsey, C. 2009. Bayesian analysis of radiocarbon dates. Radiocarbon 51(1):337-360. doi.org/ $10.1017 /$ S0033822200033865.

Bronk Ramsey, C. 2013. OxCal program v4.2.2. Radiocarbon Accelerator Unit, University of Oxford. c14.arch.ox.ac.uk/oxcal/OxCal.html.

Bulmer, S. 1966. Pig bone from two archaeological sites in the New Guinea Highlands. Journal of the Polynesian Society 75(4):504-505.

Bulmer, S. 1975. Settlement and economy in prehistoric Papua New Guinea: A review of the archaeological evidence. Journal de la Société des Océanistes 31:7-75. doi.org/10.3406/jso.1975.2688.

Bulmer, S. 1982. Human ecology and cultural variation in prehistoric New Guinea. In J.L. Gressitt (ed.), Biogeography and ecology of New Guinea 1, pp. 169-206. Monographiae Biologicae 42. Junk, The Hague. doi.org/10.1007/978-94-009-8632-9_8.

Burley, D.V. 2007. In search of Lapita and Polynesian plainware settlements in Vava u, Kingdom of Tonga. In S. Bedford, C. Sand and S.P. Connaughton (eds), Oceanic explorations: Lapita and Western Pacific settlement, pp. 187-198. Terra Australis 26. ANU E Press, Canberra. doi.org/10.22459/ TA26.2007.

Chen, C.-P. and K.-H. Chang 1981. Reproductive periodicity of the sea urchin, Tripneustes gratilla (L.) in Taiwan compared with other regions. International Journal of Invertebrate Reproduction 3(6):309319. doi.org/10.1080/01651269.1981.10553406.

Coffey Natural Systems 2009. PNG LNG Project. Environmental impact statement. Unpublished. Coffey Natural Systems Pty Ltd, Abbotsford.

David, B. 2002. Landscapes, Rock-Art and the Dreaming: An archaeology of preunderstanding. Leicester University Press, London.

David, B., I.J. McNiven, T. Richards, S.P. Connaughton, M. Leavesley, B. Barker and C. Rowe 2011. Lapita sites in the Central Province of mainland Papua New Guinea. World Archaeology 43(4):576593. doi.org/10.1080/00438243.2011.624720.

David, B., I.J. McNiven, M. Leavesley, B. Barker, H. Mandui, T. Richards and R. Skelly 2012. A new ceramic assemblage from Caution Bay, south coast of mainland PNG: The Linear Shell End-Impressed Tradition from Bogi 1. Journal of Pacific Archaeology 3:73-89.

David, B., H. Jones-Amin, T. Richards, J. Mialanes, B. Asmussen, F. Petchey, K. Aplin, M. Leavesley, I.J. McNiven, C. Zetzmann, C. Rowe, R. Skelly, R. Jenkins, P. Faulkner and S. Ulm 2016. Ruisasi 1 and the earliest evidence of mass-produced ceramics in Caution Bay (Port Moresby region), Papua New Guinea. Journal of Pacific Archaeology 7(1):41-60. 
Davies, H.L and I.E. Smith 1971. Geology of eastern Papua. Geological Society of America Bulletin 82:3299-3312. doi.org/10.1130/0016-7606(1971)82[3299:GOEP]2.0.CO;2.

Denham, T., C. Bronk Ramsey and J. Specht 2012. Dating the appearance of Lapita pottery in the Bismarck Archipelago and its dispersal to Remote Oceania. Archaeology in Oceania 47(1):39-46. doi.org/10.1002/j.1834-4453.2012.tb00113.x.

Derrida, J. 1968. Différance. Bulletin de la Société Française de Philosophie 62(3):73-101.

Dwyer, P.D. and M. Minnegal 1992. Cassowaries, chickens and change: Animal domestication by Kubo of Papua New Guinea. Journal of the Polynesian Society 101:373-385.

Fox, R. 1970. The Tabon Caves. National Museum of the Philippines, Manila.

Glaessner, M.F. 1952. Geology of Port Moresby, Papua. In M.F. Glaessner and E.A. Rudd (eds), Sir Douglas Mawson anniversary volume: Contributions to geology in honour of Professor Sir Douglas Mawson's 70th birthday anniversary presented by colleagues, friends and pupils, pp. 63-86. The University of Adelaide, Adelaide.

Golson, J. 1991. Introduction: Transitions to agriculture in the Pacific region. Bulletin of the Indo-Pacific Prehistory Association 11:48-53. doi.org/10.7152/bippa.v11i0.11372.

Gurven, M. 2004. To give and to give not: The behavioral ecology of human food transfers. Behavioral and Brain Sciences 27(4):543-559. doi.org/10.1017/S0140525X04000123.

Hide, R. 2003. Pig husbandry in New Guinea: A literature review and bibliography. ACIAR Monograph 108. Australian Centre for International Agricultural Research, Canberra.

Kirch, P.V. 1997. The Lapita peoples: Ancestors of the Oceanic world. Blackwell, Oxford.

Mabbutt, J.A, P.C. Heyligers, R.M. Scott, J.G. Speight, E.A. Fitzpatrick, J.R. McAlpine and R. Pullen 1965. Lands of the Port-Moresby-Kairuku Area, Territory of Papua and New Guinea. Land Research Series 14. CSIRO, Melbourne.

McNiven, I.J., B. David, T. Richards, K. Aplin, B. Asmussen, J. Mialanes, M. Leavesley, P. Faulkner and S. Ulm 2011. New direction in human colonisation of the Pacific: Lapita settlement of south coast New Guinea. Australian Archaeology 72:1-6. doi.org/10.1080/03122417.2011.11690525.

McNiven, I.J., B. David, K. Aplin, J. Mialanes, B. Asmussen, S. Ulm, P. Faulkner, C. Rowe and T. Richards 2012. Terrestrial engagements by terminal Lapita maritime specialists on the southern Papuan coast. In S.G. Haberle and B. David (eds), Peopled landscapes: Archaeological and biogeographic approaches to landscapes, pp. 121-156. Terra Australis 34. ANU E Press, Canberra. doi.org/10.22459/ TA34.01.2012.05.

Mialanes, J., B. David, A. Ford, T. Richards, I.J. McNiven, G.R. Summerhayes and M. Leavesley 2016. Imported obsidian at Caution Bay, south coast of Papua New Guinea: Cessation of long-distance procurement c. 1,900 cal. BP. Australian Archaeology 82(3):248-262. doi.org/10.1080/03122417. 2016.1252079 .

Nojima, S. and H. Mukai 1985. A preliminary report on the distribution pattern, daily activity and moving pattern of a seagrass grazer, Tripneustes gratilla (L.) (Echinodermata, Echinoidea) in Papua New Guinea seagrass beds. Special Publication of the Mukaishima Marine Biological Station, pp. 173-183. Mukaishima Rinkai Jikkenjo, Hiroshima.

O'Connor, S., A. Barham, K. Aplin, K. Dobney, A. Fairbairn and M. Richards 2011. The power of paradigms: Examining the evidential basis for early to mid-Holocene pigs and pottery in Melanesia. Journal of Pacific Archaeology 2(2):1-25. 
Pernetta, J.C. and I. Hill 1981. Consumer/producer societies in Papua New Guinea: The face of change. In D. Denoon and C. Snowden (eds), A history of agriculture in Papua New Guinea, pp. 283-309. Institute of Papua New Guinea Studies, Boroko.

Petchey, F., S. Ulm, B. David, I.J. McNiven, B. Asmussen, H. Tomkins, T. Richards, C. Rowe, M. Leavesley, H. Mandui and J. Stanisic 2012. ${ }^{14} \mathrm{C}$ marine reservoir variability in herbivores and deposit-feeding gastropods from an open coastline, Papua New Guinea. Radiocarbon 54(3-4):967978. doi.org/10.1017/S0033822200047603.

Petchey, F., S. Ulm, B. David, I.J. McNiven, B. Asmussen, H. Tomkins, N. Dolby, K. Aplin, T. Richards, C. Rowe, M. Leavesley and H. Mandui 2013. High-resolution radiocarbon dating of marine materials in archaeological contexts: Radiocarbon marine reservoir variability between Anadara, Gafrarium, Batissa, Polymesoda spp. and Echinoidea at Caution Bay, southern coastal Papua New Guinea. Archaeological and Anthropological Sciences 5:69-80. doi.org/10.1007/s12520-012-0108-1.

Petchey, F., M. Spriggs, S. Bedford, F. Valentin and H.R. Buckley 2014. Radiocarbon dating of burials from the Teouma Lapita cemetery, Efate, Vanuatu. Journal of Archaeological Science 50:227-242. doi.org/10.1016/j.jas.2014.07.002.

Pieters, P.E. 1978. Port Moresby, Kalo, Aroa: Papua New Guinea. Sheets SC/55-6, -7 and-11. Explanatory notes and 1:250,000 geological map. Dept. of National Development, Bureau of Mineral Resources, Geology and Geophysics. Dept. of Minerals and Energy, Papua New Guinea, Geological Survey of Papua New Guinea. Australian Government Publishing Service, Canberra.

Reimer, P.J., E. Bard, A. Bayliss, J.W. Beck, P.G. Blackwell, C. Bronk Ramsey, C.E. Buck, H. Cheng, R.L. Edwards, M. Friedrich, P.M. Grootes, T.P. Guilderson, H. Haflidason, I. Hajdas, C. Hatte, T.J. Heaton, D.L. Hoffmann, A.G. Hogg, K.A. Hughen, K.F. Kaiser, B. Kromer, S. W. Manning, M. Niu, R.W. Reimer, D.A. Richards, E.M. Scott, J.R. Southon, R.A. Staff, C.S.M. Turney and J. van der Plicht 2013. IntCal13 and Marine13 radiocarbon age calibration curves 0-50,000 years cal. BP. Radiocarbon 55:1869-1887. doi.org/10.2458/azu_js_rc.55.16947.

Roth, W.E. 1904. Domestic implements, arts and manufactures. North Queensland Ethnography Bulletin 7:1-34. Government Printer, Brisbane.

Sheppard, P.J., T. Thomas and G.R. Summerhayes (eds) 2009. Lapita: Ancestors and descendants. New Zealand Archaeological Association Monograph Series No. 28. New Zealand Archaeological Association, Auckland.

Shipman, P., G. Foster and M. Schoeninger 1984. Burnt bones and teeth: An experimental study of color, morphology, crystal structure and shrinkage. Journal of Archaeological Science 11:307-325. doi.org/ 10.1016/0305-4403(84)90013-X.

Skelly, R.J. and B. David 2017. Hiri: Archaeology of long-distance maritime trade along the south coast of Papua New Guinea. University of Hawai'i Press, Honolulu.

Smith, I.E. and J.S. Milsom 1984. Late Cenozoic volcanism and extension in Eastern Papua. Geological Society, London, Special Publications 16:163-171. doi.org/10.1144/GSL.SP.1984.016.01.12.

Spriggs, M. 1996. Chronology and colonisation in Island Southeast Asia and the Pacific: New data and an evaluation. In J.M. Davidson, G. Irwin, B.F. Leach, A. Pawley and D. Brown (eds), Oceanic culture history: Essays in honour of Roger Green, pp. 33-55. New Zealand Journal of Archaeology Special Publication, Auckland.

Spriggs, M. and S. Bedford 2013. Is there an incised Lapita phase after dentate-stamped pottery ends? Data from Teouma, Efate Island, Vanuatu. In G.R. Summerhayes and H. Buckley (eds), Pacific archaeology: Documenting the past 50,000 years, pp. 148-156. University of Otago Studies in Archaeology 25. University of Otago, Dunedin. 
Summerhayes, G.R. 2000. Lapita interaction. Terra Australis 15. Department of Archaeology and Natural History and the Centre for Archaeological Research, The Australian National University, Canberra.

Szabó, K. 2011. An analysis of marine mollusk shells from the Seven Site, Nikumaroro atoll, Phoenix Islands, Republic of Kiribati. Unpublished PIPA report.

Szabó, K. and A. Anderson 2012. The Tangarutu invertebrate fauna. In A. Anderson and D.J. Kennett (eds), Taking the high ground: The archaeology of Rapa, a fortified island in Remote East Polynesia, pp. 135-144. Terra Australis 37. ANU E Press, Canberra. doi.org/10.22459/TA37.11.2012.08.

Szabó, K., Y. Vogel and A. Anderson 2012. Marine resource exploitation on Rapa: Archaeology, material culture and ethnography. In A. Anderson and D.J. Kennett (eds), Taking the high ground: The archaeology of Rapa, a fortified island in Remote East Polynesia, pp. 145-166. Terra Australis 37. ANU E Press, Canberra. doi.org/10.22459/TA37.11.2012.08.

Thomas, F.R. 2001. Mollusk habitats and fisheries in Kiribati: An assessment from the Gilbert Islands. Pacific Science 55(1):77-97. doi.org/10.1353/psc.2001.0010.

Thomas, F.R. 2002. An evaluation of central-place foraging among mollusk gatherers in Western Kiribati, Micronesia: Linking behavioral ecology with ethnoarchaeology. World Archaeology 34(1):182-208. doi.org/10.1080/00438240220134313.

White, J.P. with J.F. O’Connell 1982. A prehistory of Australia, New Guinea and Sahul. Academic Press, North Ryde. 
This text is taken from Debating Lapita: Distribution, Chronology, Society and Subsistence, edited by Stuart Bedford and Matthew Spriggs, published 2019 by ANU Press,

The Australian National University, Canberra, Australia.

doi.org/10.22459/TA52.2019.03 